\title{
Prevalence of hereditary tubulointerstitial kidney diseases in the German Chronic Kidney Disease study
}

Bernt Popp ${ }^{1,2,{ }^{*}}$, Arif B. Ekici ${ }^{1, *}$, Karl X. Knaup ${ }^{3}$, Karen Schneider ${ }^{3}$, Steffen Uebe ${ }^{1}$, Jonghun Park $^{4}$, Vineet Bafna ${ }^{4}$, Heike Meiselbach ${ }^{3}$, Kai-Uwe Eckardt ${ }^{3,5}$, Mario Schiffer ${ }^{3}$, André Reis ${ }^{1}$, Cornelia Kraus ${ }^{1}$, Michael Wiesener ${ }^{3}$

${ }^{1}$ Institute of Human Genetics, University Hospital Erlangen, Friedrich-Alexander University Erlangen-Nürnberg, Erlangen, Germany

${ }^{2}$ Institute of Human Genetics, University of Leipzig Hospitals and Clinics, Leipzig, Germany ${ }^{3}$ Department of Nephrology and Hypertension, University Hospital Erlangen, FriedrichAlexander Universität Erlangen-Nürnberg, Erlangen, Germany

${ }^{4}$ Department of Computer Science \& Engineering, University of California, San Diego, La Jolla, CA, USA

${ }^{5}$ Department of Nephrology and Medical Intensive Care, Charité Universitätsmedizin Berlin, Berlin, Germany

"both authors contributed equally

Running title: ADTKD prevalence in the GCKD study

\section{CORRESPONDING AUTHOR:}

Prof. Dr. Michael S. Wiesener, M.D.

Department of Nephrology and Hypertension

University Hospital Erlangen

Friedrich-Alexander-University Erlangen-Nürnberg

Ulmenweg 18

91054 Erlangen, Germany

Tel: +4991318539002

Fax: +49 91318539209

Email: michael.wiesener@uk-erlangen.de

\section{KEYWORDS}

Autosomal dominant tubulointerstitial kidney disease, ADTKD, MITKD, Mucin 1, Uromodulin 
medRxiv preprint doi: https://doi.org/10.1101/2021.09.29.21264100; this version posted September 30, 2021. The copyright holder for this preprint (which was not certified by peer review) is the author/funder, who has granted medRxiv a license to display the preprint in perpetuity.

It is made available under a CC-BY 4.0 International license.

Popp \& Ekici et al. Page 2

\section{SIGNIFICANCE STATEMENT}

CKD affects $>10 \%$ of the global population and recent studies imply that a considerable portion can be attributed to monogenic diseases, which are likely underappreciated in the clinical routine. Tubulointerstitial kidney diseases are a particularly difficult group of hereditary kidney diseases to diagnose both clinically and genetically. To investigate the prevalence of these disorders in a large CKD cohort we established a set of clinical criteria and designed a custom panel sequencing pipeline. Based on the diagnostic yield of $12.5 \%$, we recommend an algorithm to clinically select and genetically evaluate patients with increased risk for a hereditary tubulointerstitial kidney disease. 


\section{ABSTRACT}

Exome sequencing (ES) studies in chronic kidney disease (CKD) cohorts could identify pathogenic variants in $\sim 10 \%$ of patients. This implies underdiagnosis of hereditary CKD. Tubulointerstitial kidney diseases, showing no typical clinical/histologic finding but tubulointerstitial fibrosis, are particularly difficult to diagnose.

We used a custom designed targeted panel (29 genes) and MUC1-SNaPshot to sequence 271 DNA samples, selected by clinical criteria from 5,217 individuals in the German Chronic Kidney Disease (GCKD) cohort.

We identified 33 pathogenic small variants. Of these 27 (81.8\%) were in COL4-genes, the largest group being 15 COL4A5-variants with nine unrelated individuals carrying c. $1871 \mathrm{G}>\mathrm{A}$, p.(Gly624Asp). We found three cysteine variants in $U M O D$, a novel missense, and a novel splice variant in HNF1B and the homoplastic MTTF variant m.616T>C. Copy-number analysis identified a heterozygous COL4A5-deletion, and a HNF1B-duplication/-deletion, respectively. Overall, pathogenic variants were present in $12.5 \%(34 / 271)$ and variants of unknown significance in $9.6 \%(26 / 271)$ of selected individuals. Bioinformatic predictions paired with gold standard diagnostics for MUC1 (SNaPshot) could not identify the typical cytosine duplication ("c.428dupC") in any individual, implying that ADTKD-MUC1 is rare.

Our study shows that $>10 \%$ of individuals with certain clinical features carry disease variants in genes associated with tubulointerstitial kidney diseases. COL4-genes constitute the largest fraction, implying they are overlooked using clinical Alport-syndrome criteria. We also identified variants easily missed by some ES pipelines. Finally, our results indicate that the filtering criteria applied enrich for an underlying genetic disorder. 
medRxiv preprint doi: https://doi.org/10.1101/2021.09.29.21264100; this version posted September 30, 2021. The copyright holder for this

preprint (which was not certified by peer review) is the author/funder, who has granted medRxiv a license to display the preprint in perpetuity.

It is made available under a CC-BY 4.0 International license .

Popp \& Ekici et al. Page 4

\section{INTRODUCTION}

Genetic kidney diseases are underdiagnosed, yet recent data imply that they are much more frequent than the clinical perception. The complexity amongst hereditary kidney diseases is high, with more than 200 diseases and considerably more candidate genes being associated. ${ }^{1,2}$ A systematic approach using exome sequencing (ES) in a cohort of more than 3.000 patients with chronic kidney disease (CKD) has recently yielded diagnostic variants in almost $10 \%$ of patients. ${ }^{3}$ Further studies with similar results have been published using ES on different patient cohorts, either population based or selected by specific disease entities. In these studies the diagnostic yield has been reported between $7 \%$ and $40 \%$ depending on population characteristics and selection criteria (e.g. pediatric vs. adult, syndromic vs. isolated, familial vs. simplex $)^{4}$. The number of hereditary kidney diseases is likely higher, since less clear genetic variants and genes not reliably associated with CKD have been excluded and complex genomic regions (such as repeat sequences) and diseases caused by copy number variants (CNVs) may be difficult to identify by $E S^{5}$. Furthermore, mitochondrial diseases are regularly missed since the mitochondrial genome (mtDNA) is not targeted in typical ES designs. Therefore, the true prevalence of genetic diseases among patients with CKD remains ambiguous to date.

A particularly difficult group of hereditary kidney diseases to diagnose are tubulointerstitial kidney diseases. These diseases cannot be recognized by any typical clinical or histopathological signs. They are characterized merely by progressive CKD and secondary features such as hypertension, as well as tubulointerstitial fibrosis in the kidney biopsy. Specific hereditary diseases with a fibrotic, tubulointerstitial phenotype primarily affecting the adult are autosomal dominant tubulointerstitial kidney diseases (ADTKD) ${ }^{6,7}$ and mitochondrially inherited tubulointerstitial kidney diseases (MITKD) ${ }^{8}$. Furthermore, the heterogeneous group of nephronophthisis (NPHP; considered pediatric ${ }^{9}$ ) would also meet these criteria. large investigative adult CKD cohorts have shown an unexpected highL prevalence of Collagen-4 (COL4) diseases, possibly also in patients not predicted as being affected from a primary glomerular disease ${ }^{3}$. Thus, searching for hereditary diseases with a tubulointerstitial phenotype should reasonably include genes associated with ADTKD, MITKD, NPHP and COL4-diseases. Some of these disease entities will not be detected by standard next generation sequencing (NGS) techniques, which is particularly true for ADTKD-MUC1, ${ }^{10,11}$ ADTKD-HNF1B where up to $50 \%$ of mutations consist of $\mathrm{CNVs}^{12}$ and MITKD ${ }^{8}$. Therefore, a comprehensive search for tubulointerstitial diseases should include technological options to detect these diseases.

To investigate the prevalence of these disorders in a large CKD cohort we established a set of clinical criteria to select individuals with increased risk for tubulointerstitial diseases from the $>5.000$ adult individuals previously recruited into the German Chronic Kidney Disease 
medRxiv preprint doi: https://doi.org/10.1101/2021.09.29.21264100; this version posted September 30, 2021. The copyright holder for this preprint (which was not certified by peer review) is the author/funder, who has granted medRxiv a license to display the preprint in perpetuity.

It is made available under a CC-BY 4.0 International license.

Popp \& Ekici et al. Page 5

$(G C K D)^{13,14}$ cohort. To ameliorate some of the diagnostic gaps of ES and enable rapid and high quality sequencing of our cohort, we designed a custom sequencing panel paired with a bioinformatic pipeline enabling analysis of copy number, mitochondrial variants and the MUC1-VNTR. Selected samples were subject to sequencing which was supplemented with gold-standard MUC1-dupC diagnostics by SNaPshot ${ }^{11}$.

Based on the diagnostic yield of our study and in comparison with published screenings, we recommend an algorithm to select patients with increased risk for a hereditary tubulointerstitial kidney disease for genetic diagnostics and propose sequencing assays and accompanying analysis pipelines for rare kidney diseases. 
medRxiv preprint doi: https://doi.org/10.1101/2021.09.29.21264100; this version posted September 30, 2021. The copyright holder for this preprint (which was not certified by peer review) is the author/funder, who has granted medRxiv a license to display the preprint in perpetuity.

It is made available under a CC-BY 4.0 International license .

Popp \& Ekici et al. Page 6

\section{MATERIALS AND METHODS}

\section{Ethics and study cohort}

This study adheres to the principles set out in the Declaration of Helsinki. The probands included in our study were filtered using the database of the German Chronic Kidney Disease (GCKD) cohort which enrolled 5,217 individuals. The GCKD study is registered as a national clinical study (DRKS 00003971). It was approved by local ethics review boards of all participating institutions ${ }^{14}$. The Ethical Committee of the Friedrich-Alexander University (FAU) Erlangen-Nürnberg approved the study protocol ("Prospektive BeobachtungsstudieGerman Chronic Kidney Disease (GCKD)-Studie"; Re.-Nr. 3831; decision date: 3.7.2008) representing the GCKD lead center at FAU.

The GCKD database was filtered using nine annotated categories ("nephrosclerosis", "gout", "IgA nephropathy", "chronic glomerulonephritis", "analgesic nephropathy", "interstitial nephritis", "hereditary disorders", "others", “unknown”) considering the individual's age (cutoff $<=50$ years, except "IgA nephropathy", "chronic glomerulonephritis", "analgesic nephropathy" with $<=40$ years and "hereditary disorders" with no age cutoff) as presumed leading CKD etiology. We excluded all individuals with known postrenal or primary glomerular disease etiology, known systemic disease, known status after acute kidney injury, polycystic kidneys and those with single kidneys. Biobank DNA samples were subsequently picked and analyzed for quality. All filtering and quality control steps are depicted in Figure $1 \mathrm{~A}$.

\section{Custom targeted panel design}

To design a custom panel covering genes associated with tubulointerstitial kidney disease phenotype, we screened the literature for publications on ADTKD and associated genes, which resulted in the inclusion of the five genes MUC1, UMOD, REN, HNF1B, SEC61A1 10,15-18. To investigate potential bioinformatic approaches of detecting MUC1 frameshift variants typically located in the VNTR between exon 2 and 3, custom probes covering this region were included and three individuals from families with a MUC1-dupC variant confirmed previously by SNaPshot ${ }^{11}$ and long-read sequencing ${ }^{19}$ were sequenced as controls. We also included three recently published differential diagnoses for ADTKD (genes DNAJB1, GATM, PARM) and 17 nephronophthisis genes. As individuals with ADTKD can have moderate hematuria or proteinuria we also included the three Collagen 4 genes (COL4A3, COL4A4, COL4A5). Due to the association of tubulointerstitial kidney disease with mitochondrial variants, we added capture probes covering the complete mitochondrial genome. Six gene loci on the X-chromosome (sex computation from coverage) and 24 
medRxiv preprint doi: https://doi.org/10.1101/2021.09.29.21264100; this version posted September 30, 2021. The copyright holder for this

preprint (which was not certified by peer review) is the author/funder, who has granted medRxiv a license to display the preprint in perpetuity.

It is made available under a CC-BY 4.0 International license .

Popp \& Ekici et al. Page 7

single nucleotide polymorphism (SNP; genomic fingerprinting) markers were added for quality control. Full details on the panel design can be found in File S2.

\section{Bioinformatic pipeline}

Resulting sequence files in BCL format were demultiplexed using bcl2fastq version v1.8.4 (Illumina, Inc., San Diego, CA, USA). Resulting paired reads in FASTQ format were aligned to the hg19 reference genome using BWA-MEM ${ }^{20}$ version 0.7.14-r1136. PCR duplicate reads were removed with Picard tools (http://broadinstitute.github.io/picard/) version 1.111 and local realignment of indels was performed using Genome Analysis Toolkit (GATK) ${ }^{21}$ version 3.8-0 to produce final BAM files (for alignment statistics see File S1 sheet "BAM_files").

Small variants were defined as "single nucleotide variants" (SNVs) and "small insertions or deletions" (indels) and were called from the final BAM files using GATK HaplotyeCaller ${ }^{22}$ version 4.1.4.0 in genomic variant call format (gVCF) mode. The resulting gVCF files were jointly genotyped with the GATK commands "GenomicsDBImport" and "GenotypeGVCFs" to produce one multi-sample VCF for the whole sequenced cohort. To calibrate and normalize, we split the cohort VCF by variant type using the "SelectVariants" command from GATK, applied recommended hard filtering to both variant sets using the "VariantFiltration" command, merged the filtered VCFs using "MergeVcfs" command and finally normalized and split multiallelic sites using the "LeftAlignAndTrimVariants" command to produce the final VCF.

SnpEff ${ }^{23}$ and SnpSift ${ }^{24}$ were used to annotate the resulting cohort VCF with variant consequences and information from dbNSFP ${ }^{25}$ version 4.0a. Additionally, we annotated splice prediction scores from SPIDEX/SPANR ${ }^{26}$ version 1.0 and from dbscSNV ${ }^{27}$ version 1.1 and clinical variant assessments from the ClinVar ${ }^{28}$ database (status 2020-02-10) and from HGMD ${ }^{29}$ version 2019.3.

The annotated variants were filtered to pass calibration, have an allele frequency $<5 \%$ in the cohort and $<1 \%$ in gnomAD exomes/ genomes with no homozygotes allowed, not being annotated as (likely) benign, while keeping all variants annotated as (likely) pathogenic in ClinVar. Only variants annotated as high or moderate impact on the gene product or having at least one splicing score predicting aberrant splicing were further analyzed. Compare File S3 sheet "hc-joint".

Copy number variant (CNV) calling from panel data was performed using CNVkit ${ }^{30}$ version 0.9.6. The parameters "target-avg-size" was set to 50 and "antitarget-avg-size" to 200.000 to optimize settings for the smaller panel design. The cohort was divided by the sequencing machine (MiSeq vs. HiSeq) and both sub-cohorts were randomly split into two equal sized groups which were used as control cohorts for each other. Resulting per sample CNV calls 
medRxiv preprint doi: https://doi.org/10.1101/2021.09.29.21264100; this version posted September 30, 2021. The copyright holder for this preprint (which was not certified by peer review) is the author/funder, who has granted medRxiv a license to display the preprint in perpetuity.

It is made available under a CC-BY 4.0 International license .

Popp \& Ekici et al. Page 8

were annotated with their RefSeq based gene content and aggregated into a cohort list for filtering. Compare File S3 sheet "CNVkit".

\section{Variant evaluation and confirmation}

Small variants (SNV/indel) were evaluated for their biological plausibility, examined for quality using the IGV browser and classified according to the five-tier variant classification system recommended by the American College of Medical Genetics and Genomics (ACMG) ${ }^{31}$. For carriers of a (likely) pathogenic variant in CEP290, we performed Sanger sequencing to exclude the deep intronic founder variant NM_025114.:c.2991+1655A>G (rs281865192; primers 5'-CATGGGAGTCACAGGGTAGG-3' and 5'-TGATGTTTAACGTTATCATTTTCCC3 '.

CNVs were visualized with the "scatter" and "heatmap" functions in CNVkit, They were then inspected in the IGV browser to compare their coverage profile with other samples, check the variant allele frequencies (VAF) at variant sites and search for break-point informative split reads. In the sample from individual "Ind_739404" we could identify split-reads supporting the heterozygous COL4A5 Deletion chrX:g.107731844_107920385del and confirmed the variant with exact breakpoints using allele specific PCR and Sanger sequencing (5'-AATTTGTTGCCTGTCTTTTGC-3' and 5'-TGCAGAATAAAACCCACACAAC3'). The deletion ("Ind_958149") and duplication ("Ind_207310") affecting the HNF1B locus were confirmed using the MLPA kit P241 (MRC Holland, Amsterdam, Netherlands).

\section{Analysis of the MUC1-VNTR region}

We analyzed the typical cytosine duplication ("dupC") located at variable positions in the VNTR between exons 2 and 3 of MUC1 with an established SNaPshot minisequencing protocol for all archived samples selected for panel sequencing ${ }^{11}$. Additionally, we had designed the panel to include capture probes targeting the MUC1-VNTR and included three MUC1-dupC positive controls in panel sequencing to enable bioinformatic analysis of this region. We used adVNTR ${ }^{32}$ version 1.3 .3 (https://github.com/mehrdadbakhtiari/adVNTR/) with custom settings "frameshift" mode and "vntr_id 25561" to identify indels in this complex genomic region.

\section{Comparison with published screening data in CKD}

To compare our diagnostic yield and exclude potential biases in variant classification, we compared our analysis to the largest currently published sequencing study in $C_{K D}^{3}$. We downloaded all variants from this study directly from ClinVar (SCV000809114 to SCV000809473) as submitted by the authors using a custom R language script. Such downloaded HGVS nomenclature was converted to VCF format using the batch function in 
VariantValidator (https://variantvalidator.org). We then annotated the resulting VCF file with the pipeline described above for our cohort. Additionally, we annotated whether the respective variant could be detected by our panel using the panel design browser extensible data (BED) file. To harmonize the ACMG classification for our cohort and the Groopman cohort we used the two automated AMCG classification tools integrated in VarSome (https://varsome.com) "ACMG Implementation" and VarSeq v2.2.3 "Sample ACMG Classifier" (Golden Helix, Inc., Bozeman, MT, USA; www.goldenhelix.com) for both variant sets with standard settings. We aggregated multiple (likely) pathogenic variants, as predicted by the ACMG classifiers, per individual in the Groopman cohort and performed 10.000 simulations drawing our final cohort sample size $(n=271)$ from the Groopman cohort. In each simulation we counted how many individuals could be diagnosed by our panel or by exome and how many individuals would have a (likely) pathogenic variant in COL4A5. The results of this simulation were then compared with our diagnostic yield using only variants automatically classified as (likely) pathogenic and excluding CNVs and mitochondrial variants. Results were visualized using scatter and violin plots and empirical p-values were calculated by computing how many simulations had a higher or equal yield fraction or COL4 variant fraction, respectively.

\section{Statistical analyses and plotting}

All data regarding cohort, panel content and identified variants were aggregated into Excel (Microsoft Corporation, Redmond, USA) files and are attached as supplementary to this article. These data were imported, analyzed and plotted using $R$ language version 4.1.0 with RStudio IDE version 1.4.1717 (RStudio Inc., Boston, MA, USA). Libraries "broom", "cowplot", "DiagrammeR", "DiagrammeRsvg", "fs", "fuzzyjoin", "ggrepel", "readxl", "rsvg", "tidyverse" and "UpSetR". Inkscape 1.1 (https://inkscape.org/) was used to adjust Figure 1 and Figure 2 for parts which could not be directly composed in R. Schematic linear gene plots with variant positions represented as lollipops scaled to the variant's CADD score ${ }^{33}$ were created in $\mathrm{R}$ as described previously ${ }^{34}$.

The two sided Wilcoxon signed-rank test as implemented in $\mathrm{R}$ was used to compare pairwise differences between groups (except for the $p$-values in the simulation estimated by sampling or when the question could be modelled as a Bernoulli experiment where we used the binomial test). 
medRxiv preprint doi: https://doi.org/10.1101/2021.09.29.21264100; this version posted September 30, 2021. The copyright holder for this preprint (which was not certified by peer review) is the author/funder, who has granted medRxiv a license to display the preprint in perpetuity.

It is made available under a CC-BY 4.0 International license .

Popp \& Ekici et al. Page 10

\section{RESULTS}

\section{Cohort characteristics}

Filtering initially selected 303 patients from the 5,217 individuals of the GCKD cohort (5.8\%). 287 (94.7\%) DNA samples were of sufficient quality and quantity. Further 16 (5.3\%) samples were excluded due to fingerprinting- or sex-mismatch, leaving a final cohort of $271(89.4 \%)$ individuals (Figure 1A). Most individuals fulfilled the inclusion criteria "nephrosclerosis" (94/271 34.7\%), "IgA nephropathy" (71/271 26.2\%) or "unknown" etiology (48/271 17.7\%). 21 individuals (7.7\%) were simultaneously in two filtering groups (Figure 1B). The cohort contained 158 males with a median age of 43 years (range 18 - 69 years) and 113 females with a median age of 40 years (range 18 - 66 years), giving a male to female ratio of 1.40 (Figure 1C) which is comparable with the sex ratio in the whole GCKD cohort (3132/2085 1.50). Individuals were initially included into the GCKD study following GFR estimation by MDRD study ${ }^{14}$ calculation and CKD-EPI equation based GFR estimates were subsequently performed. We compared these figures for the selected patients, showing little difference between CKD-EPI (median $55.5 \pm 24.2 \mathrm{SD} \mathrm{mL} / \mathrm{min} / 1.73 \mathrm{~m}^{2}$ ) and MDRD (median $50.0 \pm 22.0 \mathrm{SD} \mathrm{mL} / \mathrm{min} / 1.73 \mathrm{~m}^{2}$ ) (Figure 1D middle and top panel). The rate of albuminuria at inclusion into the study is expectedly low as we applied search criteria for tubulointerstitial diseases (median 182.1 \pm 886.4 SD mg/g creatinine; Figure 1D lower panel). Compare File $\mathrm{S} 1^{35}$ sheet "cohort" for details per individual.

\section{High diagnostic yield of $\mathbf{1 2 . 5} \%$ and genetic spectrum}

We identified 36 diagnostic mutations in six genes (Figure 2), which could be classified as type 4 (likely pathogenic) or 5 (pathogenic) variants (Table 1) following the $\mathrm{ACMG}^{31}$ recommendations.

The main focus of our study was to determine the prevalence of ADTKD in a representative cohort of adult patients with CKD. Regarding the classical ADTKD associated genes (MUC1, $U M O D, R E N, H N F 1 B, S E C 61 A 1)$, we found three typical cysteine variants in UMOD (NM_001278614.1: c.548G>A， p.(Cys183Tyr); c.608G>A, p.(Cys203Tyr); c.673G>T, p.(Gly225Cys)) and a novel missense (NM_000458.3: c.742C>G, p.(Gln248Glu)), and a novel canonical splice variant (NM_000458.3: c.810-1G>A, p.0?) in HNF1B. Copy-number analysis additionally identified a duplication and a deletion of $H N F 1 B$, respectively, which likely represent larger microdeletions/-duplications. No (likely) pathogenic variants were identified in REN and SEC61A1 or in the non-VNTR region of MUC1.

In the targeted mitochondrial genome we identified the homoplastic MTTF variant m.616T>C, previously described to cause MITKD ${ }^{36}$, in one male individual ("Ind_151715"). 
An overwhelming number of mutations (28/36 77.8\%) were identified in the COL4-gene group. Of the 16 diagnostic mutations in COL4A5, nine (56.3\%) were the previously reported c.1871G>A p.(Gly624Asp) variant (NM_033380.2), which appears to be a relatively frequent founder variant in Europe and is described to lead to a milder course of $C K D^{37,38}$. According to this, the individuals bearing this variant in our study were dispersed throughout Germany and our kinship calculation indicated no recent relatedness. We additionally identified a 188.5 kilobase large heterozygous COL4A5 deletion in a female individual for which we were able to determine the exact breakpoints from split reads (chrX:g.107731844_107920385del, NM_000495.4:c.81+48408_3791-345del, p.0).

All 36 (likely) pathogenic variants were identified in 34/271 of the analyzed individuals yielding a diagnostic rate of $12.5 \%$. Interestingly, two (2/34 5.9\%) female patients with the COL4A5 variant c.1871G>A, p.(Gly624Asp) showed accompanying diagnostic variants in further genes, COL4A3 (individual "Ind_553814") and HNF1B (individual "Ind_197144"), respectively. Thus, a digenic mode of inheritance or a blended phenotype from two independent disorders can be postulated, which has previously been discussed for a proportion of patients with $\mathrm{AS}^{39}$ and is in line with published numbers for multiple diagnostic loci in rare disease patients ${ }^{40}$ and adult CKD patients ${ }^{3}$. Reported variants with the respective patient's clinical criteria are listed in Table 1. Table 2 shows additional variants of unknown significance identified and Table 3 lists the (likely) pathogenic variants identified in nephronophthisis genes.

\section{Relation of clinical criteria and genetic diagnosis}

Having identified the patients with an underlying genetic disease, we re-analyzed and correlated the clinical information that was available in the GCKD database. As could be expected, the group "hereditary disorders" harboured the highest rate of patients with diagnostic mutations (10/17 58.8\%), followed by the groups "gout" (4/9 44.4\%) and "interstitial nephritis" (4/23 17.4\%) (Figure 3A). The large groups of "nephrosclerosis" and "IgA nephropathy" display lower rates of diagnostic hits with $8.4 \%(8 / 94)$ and $7.0 \%(5 / 71)$, respectively. Assuming an equal diagnostic rate for all categories as null hypothesis, only the categories "hereditary disorders" ( $p$ 0.000014; binomial test) and "gout" ( $p$ 0.023; binomial test) showed significant enrichment for genetic findings. The group "hereditary disorders" would remain significant when correcting for multiple testing at a threshold of $0.005 / 9$ ( 0.0056). By far the most diagnostic mutations involve one of the three COL4genes, which are the sole mutations in the groups "gout", "hereditary disorders" and "IgA nephropathy" (Figure 3B). The diagnostic groups "interstitial nephritis", "nephrosclerosis" and "unknown" show a higher rate of genetic heterogeneity. However, the numbers are too small to speculate about a systematic effect. 
Comparison of the GFR at inclusion into the GCKD study between the group of patients where a genetic diagnosis was identified with the rest of patients did not show a difference (Figure 3C, left and middle panel). In contrast, the albuminuria at inclusion into the study was significantly higher in the genetically determined group, which is an effect exclusively caused by the patients with AS (Figure 3C, right hand panel).

Next, we were interested in the contribution of previous kidney biopsies for the clinical evaluation, since the kidney histology is not informative for the diagnosis of ADTKD ${ }^{6,7}$, but in contrast could be helpful in recognition of COL4-diseases. Figure 3D shows that a biopsy was taken in $46.1 \%$ (125/271) of the selected patients before inclusion into the GCKD study. Interestingly, this rate was similar with $47.1 \%(8 / 17)$ in patients that were classed into the group of "hereditary disorders" and with $52.9 \%$ (18/34) in the group of patients with a diagnostic mutation. Considering only the patients with an identified COL4-disease, $63.0 \%$ $(17 / 27)$ of this group were biopsied, but only three patients $(11.1 \%)$ were previously marked with a suspected diagnosis of AS in the GCKD files (two biopsied, one not biopsied). All these three patients were correctly positioned by the nephrologists into the group "hereditary disease", where the rest of patients in this disease group were commented as "unspecified". Therefore, for the patients analysed in our study the kidney biopsy does not appear to have been of any direct diagnostic value, unless for exclusion of another disease.

\section{Comparison with published CKD cohorts confirms high diagnostic rate}

Compared to previous studies of adult CKD cohorts, our diagnostic yield of 12.5\% (34/271) is relatively high and comparable to exome sequencing, despite the relatively small number of genes in our design and exclusion of PKD1/2 associated disease. To test for the generalizability of this observation, we compared our diagnostic yield to the currently largest exome sequencing study in adults with CKD by Groopman and colleagues ${ }^{3}$. As this study did not analyze CNVs and mitochondrial variants, we also only included small variants in the autosomes and gonosomes from our study (30/271 11.1\%; excluding CNVs and mitochondrial variants) for the comparison. After harmonizing both our and the AURORA and CUMC cohorts ${ }^{3}$ using the same annotations, we performed a simulation where we randomly selected 271 individuals from the 3,315 individuals reported with diagnostic variants by Groopman et al. and then counted whether the respective variant reported would be detectable by our analysis. The simulation indicated that our diagnostic yield of $11.1 \%$ is very unlikely by chance (estimated p-value < 0.0001) (Figure 4A), and this indicates enrichment through our filtering (compare Figure 4B). 
medRxiv preprint doi: https://doi.org/10.1101/2021.09.29.21264100; this version posted September 30, 2021. The copyright holder for this

preprint (which was not certified by peer review) is the author/funder, who has granted medRxiv a license to display the preprint in perpetuity.

It is made available under a CC-BY 4.0 International license .

Popp \& Ekici et al. Page 13

\section{DISCUSSION}

CKD is frequent disease, affecting more than $10 \%$ of the global population, that is strongly associated with adverse prognosis and has a profound socioeconomic impact. ${ }^{41,42}$ In the last decade genetic diagnostics have greatly improved, which has led to the recognition of a relevant burden of hereditary causes amongst patients with CKD. In parallel, international initiatives promote targeted treatment developments for rare diseases. The aim for "precision medicine" therefore thrives for an accurate diagnosis and a effective targeted therapy. ${ }^{1,2,43}$ ES on a clinical basis in every patient with CKD is not (yet) realistic, is not standardized (e.g. different commercial designs and bioinformatic pipelines) and has diagnostic gaps for several kidney disorders. Thus, algorithms need to be defined to decide which patient should be offered genetic testing and which combinations of ES and specialized targeted analyses will result in highest diagnostic yields while being as economical as possible for the healthcare system. Possible criteria to undertake genetic analysis would be young CKD onset, disease type and a positive family history as well as the existence of extrarenal, syndromic features. ${ }^{4}$ To date, the largest genetic study published on CKD patients analyzed a virtual panel of 625 genes associated with kidney disease on an exome platform ${ }^{3}$. In this study $63 \%$ of diagnostic mutations were restricted to six genes (PKD1/2, COL4A3/4/5, $U M O D$ ). Therefore, on a clinical basis it appears appropriate to restrict the number of analyzed genes. We here used a panel of merely 29 genes to investigate the prevalence of hereditary tubulointerstitial diseases. Our rate of diagnostic findings was higher compared to Groopman et al. (12.5\% vs. $9.3 \%$ or 10.1 when including their "putatively diagnostic variants") ${ }^{3}$, which we interpret as confirmation of successful filtering criteria (Figure 4).

The majority of our diagnostic findings were amongst the COL4-genes (Figure 2), which would not normally account for tubulointerstitial but glomerular diseases. However, COL4diseases have been extensively reported as frequent unexpected diagnoses in patients with focal segmental glomerulosclerosis upon renal histology ${ }^{44}$ or broad population based analyses, ${ }^{3,45}$ where previous erroneous diagnoses may have taken place. Therefore, we decided to include the COL4-genes. The rate of COL4-mutations may be lower in other populations since about one third of the pathogenic COL4-variants we found were the COL4A5 hotspot mutation c.1871G>A (p.Gly624Asp) $(10 / 28 \sim 35.7 \%$ here vs. in the Groopman study $9 / 108 \sim 8.3 \%$ ), with a high frequency in central European populations ${ }^{37,38}$. Interestingly, looking back into the original entries of the GCKD database, of the 28 patients with a diagnostic COL4-variant, only three were previously suspected to have AS. Thus, the majority of almost $90 \%$ of COL4-diseases were clinically not recognized. Analysis of the defined AS patients for proteinuria showed a significant difference for a moderate proteinuria as compared to the group without a genetic diagnosis (Figure $3 \mathrm{C}$ ). Therefore, recognition of proteinuria could sensitize nephrologists towards COL4-diseases and encourage a restricted 
diagnostic workup. Overall, our analysis confirmed previous studies showing a high background rate of COL4-variants in CKD cohorts. Considering that two individuals with a pathogenic COL4-variant had a second pathogenic variant $(2 / 34 \sim 5.9 \%)$ and thus a dual diagnosis, it seems sensible to perform a broader search in patients with a COL4-variant, especially if the affected person shows an atypical disease course or additional features.

Further rather difficult diagnostic groups, prone to faulty classification could be "nephrosclerosis" and "IgA nephropathy", where our analysis yielded diagnostic mutations in $8.5 \%$ and $7.0 \%$ of patients, respectively (Figure $2 \mathrm{~A}$ ). Although these groups showed no statistically significant enrichment, when compared to the baseline diagnostic yield in our cohort, they could motivate clinicians to look more careful at individual patients before diagnostic classification. Naturally, the great majority of CKD patients will show arterial hypertension and often it will not be clear if this is the cause or sequel of CKD. Similar challenges can be met with the histological diagnosis of "IgA nephropathy", which can be found in a substantial fraction of the (healthy) population. ${ }^{46-48}$ Therefore, parallel and possibly more severe diagnoses such as ADTKD can be overlooked. ${ }^{49}$

Our study investigated a diagnostically particularly difficult group of patients with hereditary tubulointerstitial diseases. Since patients suffering from ADTKD usually reach ESRD between the 3rd and 6th decade of life ${ }^{6,7}$ and the GCKD inclusion criteria was CKD stage 3 ${ }^{14}$, we set the age cut-off for most leading diagnoses to 40 or 50 years of age (see Methods). This stringent age-related cut-off accepts that single patients may be missed with an exceptionally mild phenotype, which however is rarely the case with ADTKD. ${ }^{50,51}$ The comprehensive diagnostic difficulties are clinical and histological but also methodological in terms of molecular genetics. As such, respective candidate genes may have frequent CNVs (i.e. HNF1B), are not contained in usual genetic screens (mitochondrial genome) or show complex repeat structures (i.e. MUC1). In the absence of a family history it is very difficult to raise a clinical suspicion of these diseases. Therefore, we suspect that patients with sporadic disease will hardly be recognized. Thus, the prevalence of these diseases are not known to date. We identified seven mutations in known genes for ADTKD which represent $2,6 \%(7 / 271)$ of the sequenced cohort. Interpolating to the total GCKD cohort, while assuming complete enrichment through our criteria, this would mean a prevalence of $0.13 \%$ $(7 / 5,217)$. Interestingly, this figure is similar to another recent study with the estimate of $0.54 \%$ for patients with ADTKD in the complete ESRD cohort of Ireland ${ }^{52}$ and the diagnostic yield for ADTKD variants reported by Groopman et al. with $0.39 \%(13 / 3,315)$. Importantly, none of the 7 individuals with diagnostic ADTKD mutations were originally grouped as suffering from a "hereditary disorder". These patients were originally classed as "nephrosclerosis" (3x), "interstitial nephritis" (3x), "others" (1x) and "unknown" (1x) (see Table 1). Therefore, we presume that the majority of these diseases could be sporadic. 
While we present a detailed analysis of the prevalence of hereditary tubulointerstitial kidney diseases, it is important to consider confounders. First, any selection strategy has the potential to miss patients. Thus, the true figure of hereditary disease will presumably be higher than our results. Second, we performed a screening limited by a customized gene panel which can miss other causative mutations. However, the focus of our study was ADTKD and related diseases, which were tested exhaustively. Third, we classed the variants following the recommendation of the $\mathrm{ACMG}^{31}$, where class $3 \mathrm{VUS}$ are not contained in our yield calculations. We performed a detailed analysis of these VUS (Table 2). However, it currently remains unknown how many of them in fact are the reason for CKD in individual patients and further population and functional studies (e.g. saturation mutagenesis) will be needed to elucidate their effects. Fourth, we did not include the genes recommended to be reported as secondary findings ${ }^{53}$, which are expected in $\sim 1 \%$ of the population and are of clinical relevance especially for CKD patients with chronic dialysis or immunosuppression ${ }^{4}$. In summary, ADTKD/MITKD are quite rare in the CKD population. With limitations in financial resources, it is probably not justified to broadly perform targeted ADTKD diagnostics in the clinical routine. This is particularly true for ADTKD-MUC1, where testing for the "dupC"-mutation using SNaPshot is laborious and did not lead to a single hit here. On the other hand, our bioinformatic assessment of the targeted VNTR region showed complete agreement. Also, when clinical criteria are present and a clear autosomal dominant pedigree evident, the rate of diagnostic mutations for ADTKD is reasonably high. ${ }^{50,54}$ Based on these considerations, our and other's results and experience from rare disease studies we recommend a clinically enhanced ES design paired with customized bioinformatics (Figure $5 \mathrm{~A}$ ) and an iteration of genetic diagnostics and research re-evaluation (Figure 5B). Only by establishing such comprehensive workflows in centers for rare kidney diseases will we be able to improve diagnostics, gather further knowledge on each genetic CKD entity and finally improve outcome. 
medRxiv preprint doi: https://doi.org/10.1101/2021.09.29.21264100; this version posted September 30, 2021. The copyright holder for this preprint (which was not certified by peer review) is the author/funder, who has granted medRxiv a license to display the preprint in perpetuity. It is made available under a CC-BY 4.0 International license .

Popp \& Ekici et al. Page 16

\section{AUTHORS CONTRIBUTIONS}

M.W., B.P. and A.B.E. conceived the initial study concept. M.W. curated the clinical criteria and filtered/ selected the cohort. A.B.E., M.W., and B.P. created the panel gene list. A.B.E., M.S., and K.U.E. collected the samples from the GCKD cohort and provided clinical and chromosomal microarray data. A.B.E. coordinated panel design, DNA sample processing and all sequencing. S.U. and B.P. performed tertiary bioinformatic analyses. J.P. and V.B. developed adVNTR and analyzed the MUC1-VNTR panel data. K.S., K.K. and A.B.E. performed the MUC1-SNaPshot analysis. U.A. aided in the validation and classification of mitochondrial variants. A.R. and C.K. performed variant validation and aided in quality control. B.P. performed variant calling, annotation, classification and upload to public databases. B.P. analyzed the variant and clinical data and created all figures/ tables and the Supplementary materials. B.P. and M.W. wrote and edited the manuscript. All authors reviewed and commented on the final draft manuscript.

\section{ACKNOWLEDGEMENTS}

We thank all involved individuals for participating in the GCKD study. We also thank the large number of nephrologists for their support of the GCKD study (list of nephrologists currently collaborating with the GCKD study is available at http://www.gckd.org). The GCKD Investigators are listed in the Supplementary Notes. We would like to thank Susanne Becker for valuable assistance with data analysis of GCKD. We would like to thank Petra Rothe, Angelika Diem and Daniela Schweitzer for excellent technical assistance. We thank Uwe Ahting (Institute of Human Genetics, Technische Universität München, Munich, Germany) for aiding with the interpretation of mitochondrial variants.

\section{DISCLOSURES}

All authors involved in the study declare no conflicts of interest relevant to this study.

\section{FUNDING}

The studies were funded by the Deutsche Forschungsgemeinschaft (DFG, German Research Foundation) - Projektnummer 387509280 - SFB 1350, TP C4. In addition an unrestricted donation to the Department of Nephrology and Hypertension was used from Fischer Business Technology GmbH in Grasbrunn / München. Bernt Popp is supported by the Deutsche Forschungsgemeinschaft (DFG) through grant PO2366/2-1. The GCKD study was/is supported by Bundesministerium für Bildung und Forschung and Kuratorium für Heimdialyse und Nierentransplantation e.V.-Stiftung Präventivmedizin, and corporate sponsors. 
medRxiv preprint doi: https://doi.org/10.1101/2021.09.29.21264100; this version posted September 30, 2021. The copyright holder for this preprint (which was not certified by peer review) is the author/funder, who has granted medRxiv a license to display the preprint in perpetuity.

It is made available under a CC-BY 4.0 International license .

Popp \& Ekici et al. Page 17

\section{REFERENCES}

1. Devuyst O, Knoers NVAM, Remuzzi G, Schaefer F, Board of the Working Group for Inherited Kidney Diseases of the European Renal Association and European Dialysis and Transplant Association. Rare inherited kidney diseases: challenges, opportunities, and perspectives. Lancet Lond Engl. 2014;383(9931):1844-1859. doi:10.1016/S01406736(14)60659-0

2. Rasouly HM, Groopman EE, Heyman-Kantor R, et al. The Burden of Candidate Pathogenic Variants for Kidney and Genitourinary Disorders Emerging From Exome Sequencing. Ann Intern Med. 2019;170(1):11. doi:10.7326/M18-1241

3. Groopman EE, Marasa M, Cameron-Christie S, et al. Diagnostic Utility of Exome Sequencing for Kidney Disease. N Engl J Med. 2019;380(2):142-151.

doi:10.1056/NEJMoa1806891

4. Cocchi E, Nestor JG, Gharavi AG. Clinical Genetic Screening in Adult Patients with Kidney Disease. Clin J Am Soc Nephrol CJASN. 2020;15(10):1497-1510. doi:10.2215/CJN.15141219

5. Hays T, Groopman EE, Gharavi AG. Genetic testing for kidney disease of unknown etiology. Kidney Int. 2020;98(3):590-600. doi:10.1016/j.kint.2020.03.031

6. Eckardt K-U, Alper SL, Antignac C, et al. Autosomal dominant tubulointerstitial kidney disease: diagnosis, classification, and management--A KDIGO consensus report. Kidney Int. 2015;88(4):676-683. doi:10.1038/ki.2015.28

7. Devuyst O, Olinger E, Weber S, et al. Autosomal dominant tubulointerstitial kidney disease. Nat Rev Dis Primer. 2019;5(1):60. doi:10.1038/s41572-019-0109-9

8. Connor TM, Hoer S, Mallett A, et al. Mutations in mitochondrial DNA causing tubulointerstitial kidney disease. Larsson N-G, ed. PLOS Genet. 2017;13(3):e1006620. doi:10.1371/journal.pgen.1006620

9. Braun DA, Hildebrandt F. Ciliopathies. Cold Spring Harb Perspect Biol. 2017;9(3). doi:10.1101/cshperspect.a028191

10. Kirby A, Gnirke A, Jaffe DB, et al. Mutations causing medullary cystic kidney disease type 1 lie in a large VNTR in MUC1 missed by massively parallel sequencing. Nat Genet. 2013;45(3):299-303. doi:10.1038/ng.2543

11. Ekici $A B$, Hackenbeck $T$, Morinière $V$, et al. Renal fibrosis is the common feature of autosomal dominant tubulointerstitial kidney diseases caused by mutations in mucin 1 or uromodulin. Kidney Int. 2014;86(3):589-599. doi:10.1038/ki.2014.72

12. Ferrè $S$, Igarashi $P$. New insights into the role of HNF-1 $\beta$ in kidney (patho)physiology. Pediatr Nephrol Berl Ger. 2019;34(8):1325-1335. doi:10.1007/s00467-018-3990-7

13. Titze $S$, Schmid M, Köttgen A, et al. Disease burden and risk profile in referred patients with moderate chronic kidney disease: composition of the German Chronic Kidney Disease (GCKD) cohort. Nephrol Dial Transplant Off Publ Eur Dial Transpl Assoc - Eur Ren Assoc. 2015;30(3):441-451. doi:10.1093/ndt/gfu294

14. Eckardt K-U, Barthlein B, Baid-Agrawal S, et al. The German Chronic Kidney Disease (GCKD) study: design and methods. Nephrol Dial Transplant. 2012;27(4):1454-1460. doi:10.1093/ndt/gfr456

15. Lindner TH, Njolstad PR, Horikawa Y, Bostad L, Bell GI, Sovik O. A novel syndrome of diabetes mellitus, renal dysfunction and genital malformation associated with a partial deletion of the pseudo-POU domain of hepatocyte nuclear factor-1beta. Hum Mol Genet. 1999;8(11):2001-2008. doi:10.1093/hmg/8.11.2001

16. Zivná $M$, Hůlková $H$, Matignon $M$, et al. Dominant renin gene mutations associated with early-onset hyperuricemia, anemia, and chronic kidney failure. Am J Hum Genet. 2009;85(2):204-213. doi:10.1016/j.ajhg.2009.07.010

17. Bolar NA, Golzio C, Živná M, et al. Heterozygous Loss-of-Function SEC61A1 Mutations Cause Autosomal-Dominant Tubulo-Interstitial and Glomerulocystic Kidney Disease with Anemia. Am J Hum Genet. 2016;99(1):174-187. doi:10.1016/j.ajhg.2016.05.028

18. Hart TC, Gorry MC, Hart PS, et al. Mutations of the UMOD gene are responsible for medullary cystic kidney disease 2 and familial juvenile hyperuricaemic nephropathy. $J$ 
medRxiv preprint doi: https://doi.org/10.1101/2021.09.29.21264100; this version posted September 30, 2021. The copyright holder for this preprint (which was not certified by peer review) is the author/funder, who has granted medRxiv a license to display the preprint in perpetuity.

It is made available under a CC-BY 4.0 International license .

Popp \& Ekici et al. Page 18

Med Genet. 2002;39(12):882-892. doi:10.1136/jmg.39.12.882

19. Wenzel A, Altmueller J, Ekici $A B$, et al. Single molecule real time sequencing in ADTKD-MUC1 allows complete assembly of the VNTR and exact positioning of causative mutations. Sci Rep. 2018;8(1):4170. doi:10.1038/s41598-018-22428-0

20. $\mathrm{Li} \mathrm{H}$. Aligning sequence reads, clone sequences and assembly contigs with BWAMEM. ArXiv13033997 Q-Bio. Published online May 26, 2013. Accessed July 11, 2021. http://arxiv.org/abs/1303.3997

21. McKenna A, Hanna M, Banks E, et al. The Genome Analysis Toolkit: A MapReduce framework for analyzing next-generation DNA sequencing data. Genome Res. 2010;20(9):1297-1303. doi:10.1101/gr.107524.110

22. Poplin R, Ruano-Rubio V, DePristo MA, et al. Scaling Accurate Genetic Variant Discovery to Tens of Thousands of Samples. Genomics; 2017. doi:10.1101/201178

23. Cingolani P, Platts A, Wang LL, et al. A program for annotating and predicting the effects of single nucleotide polymorphisms, SnpEff: SNPs in the genome of Drosophila melanogaster strain w1118; iso-2; iso-3. Fly (Austin). 2012;6(2):80-92. doi:10.4161/fly. 19695

24. Cingolani P, Patel VM, Coon M, et al. Using Drosophila melanogaster as a Model for Genotoxic Chemical Mutational Studies with a New Program, SnpSift. Front Genet. 2012;3. doi:10.3389/fgene.2012.00035

25. Liu X, Li C, Mou C, Dong Y, Tu Y. dbNSFP v4: a comprehensive database of transcriptspecific functional predictions and annotations for human nonsynonymous and splicesite SNVs. Genome Med. 2020;12(1):103. doi:10.1186/s13073-020-00803-9

26. Xiong HY, Alipanahi B, Lee LJ, et al. The human splicing code reveals new insights into the genetic determinants of disease. Science. 2015;347(6218):1254806-1254806. doi:10.1126/science.1254806

27. Jian X, Boerwinkle E, Liu X. In silico prediction of splice-altering single nucleotide variants in the human genome. Nucleic Acids Res. 2014;42(22):13534-13544. doi:10.1093/nar/gku1206

28. Landrum MJ, Lee JM, Benson M, et al. ClinVar: improving access to variant interpretations and supporting evidence. Nucleic Acids Res. 2018;46(D1):D1062D1067. doi:10.1093/nar/gkx1153

29. Stenson PD, Ball EV, Mort M, et al. Human Gene Mutation Database (HGMD $\left.{ }^{\circledR}\right): 2003$ update: HGMD 2003 UPDATE. Hum Mutat. 2003;21(6):577-581.

doi:10.1002/humu.10212

30. Talevich E, Shain AH, Botton T, Bastian BC. CNVkit: Genome-Wide Copy Number Detection and Visualization from Targeted DNA Sequencing. PLOS Comput Biol. 2016;12(4):e1004873. doi:10.1371/journal.pcbi.1004873

31. Richards S, Aziz N, Bale S, et al. Standards and guidelines for the interpretation of sequence variants: a joint consensus recommendation of the American College of Medical Genetics and Genomics and the Association for Molecular Pathology. Genet Med Off J Am Coll Med Genet. 2015;17(5):405-424. doi:10.1038/gim.2015.30

32. Bakhtiari M, Park J, Ding Y-C, et al. Variable number tandem repeats mediate the expression of proximal genes. Nat Commun. 2021;12(1):2075. doi:10.1038/s41467021-22206-z

33. Rentzsch P, Witten D, Cooper GM, Shendure J, Kircher M. CADD: predicting the deleteriousness of variants throughout the human genome. Nucleic Acids Res. 2019;47(D1):D886-D894. doi:10.1093/nar/gky1016

34. Hebebrand M, Hüffmeier U, Trollmann R, et al. The mutational and phenotypic spectrum of TUBA1A-associated tubulinopathy. Orphanet J Rare Dis. 2019;14(1):38. doi:10.1186/s13023-019-1020-x

35. Popp, Bernt. Data files for manuscript "Prevalence of hereditary tubulointerstitial kidney diseases in the German Chronic Kidney Disease study." Published online September 19, 2021. doi:10.5281/ZENODO.5516388

36. Lorenz R, Ahting U, Betzler C, Heimering S, Borggräfe I, Lange-Sperandio B. Homoplasmy of the Mitochondrial DNA Mutation m.616T\&\#x3e;C Leads to 
medRxiv preprint doi: https://doi.org/10.1101/2021.09.29.21264100; this version posted September 30, 2021. The copyright holder for this preprint (which was not certified by peer review) is the author/funder, who has granted medRxiv a license to display the preprint in perpetuity.

It is made available under a CC-BY 4.0 International license .

Popp \& Ekici et al. Page 19

Mitochondrial Tubulointerstitial Kidney Disease and Encephalopathia. Nephron. 2020;144(3):156-160. doi:10.1159/000504412

37. Pierides A, Voskarides K, Kkolou M, Hadjigavriel M, Deltas C. X-linked, COL4A5 hypomorphic Alport mutations such as G624D and P628L may only exhibit thin basement membrane nephropathy with microhematuria and late onset kidney failure. Hippokratia. 2013;17(3):207-213.

38. Zurowska AM, Bielska O, Daca-Roszak P, et al. Mild X-linked Alport syndrome due to the COL4A5 G624D variant originating in the Middle Ages is predominant in Central/East Europe and causes kidney failure in midlife. Kidney Int. 2021;99(6):14511458. doi:10.1016/j.kint.2020.10.040

39. Mencarelli MA, Heidet L, Storey $\mathrm{H}$, et al. Evidence of digenic inheritance in Alport syndrome. J Med Genet. 2015;52(3):163-174. doi:10.1136/jmedgenet-2014-102822

40. Posey JE, Harel T, Liu P, et al. Resolution of Disease Phenotypes Resulting from Multilocus Genomic Variation. N Engl J Med. 2017;376(1):21-31. doi:10.1056/NEJMoa1516767

41. Glassock RJ, Warnock DG, Delanaye P. The global burden of chronic kidney disease: estimates, variability and pitfalls. Nat Rev Nephrol. 2017;13(2):104-114. doi:10.1038/nrneph.2016.163

42. Levin A, Tonelli M, Bonventre J, et al. Global kidney health 2017 and beyond: a roadmap for closing gaps in care, research, and policy. The Lancet. 2017;390(10105):1888-1917. doi:10.1016/S0140-6736(17)30788-2

43. Vivante A, Hildebrandt F. Exploring the genetic basis of early-onset chronic kidney disease. Nat Rev Nephrol. 2016;12(3):133-146. doi:10.1038/nrneph.2015.205

44. Papazachariou L, Papagregoriou G, Hadjipanagi D, et al. Frequent COL4 mutations in familial microhematuria accompanied by later-onset Alport nephropathy due to focal segmental glomerulosclerosis. Clin Genet. 2017;92(5):517-527. doi:10.1111/cge.13077

45. Lata S, Marasa M, Li Y, et al. Whole-Exome Sequencing in Adults With Chronic Kidney Disease: A Pilot Study. Ann Intern Med. 2018;168(2):100. doi:10.7326/M17-1319

46. Waldherr R, Rambausek M, Duncker WD, Ritz E. Frequency of mesangial IgA deposits in a non-selected autopsy series. Nephrol Dial Transplant Off Publ Eur Dial Transpl Assoc - Eur Ren Assoc. 1989;4(11):943-946. doi:10.1093/ndt/4.11.943

47. Varis J, Rantala I, Pasternack A, et al. Immunoglobulin and complement deposition in glomeruli of 756 subjects who had committed suicide or met with a violent death. $J$ Clin Pathol. 1993;46(7):607-610. doi:10.1136/jcp.46.7.607

48. Suzuki K, Honda K, Tanabe K, Toma H, Nihei H, Yamaguchi Y. Incidence of latent mesangial IgA deposition in renal allograft donors in Japan. Kidney Int. 2003;63(6):2286-2294. doi:10.1046/j.1523-1755.63.6s.2.x

49. Knaup KX, Büttner-Herold M, Popp B, et al. The Dilemma of Regularly Missed Diagnoses: ADTKD. Arch Clin Med Case Rep. 2019;03(06). doi:10.26502/acmcr.96550127

50. Olinger E, Hofmann P, Kidd K, et al. Clinical and genetic spectra of autosomal dominant tubulointerstitial kidney disease due to mutations in UMOD and MUC1. Kidney Int. 2020;98(3):717-731. doi:10.1016/j.kint.2020.04.038

51. Bleyer AJ, Kmoch S, Antignac C, et al. Variable clinical presentation of an MUC1 mutation causing medullary cystic kidney disease type 1. Clin J Am Soc Nephrol CJASN. 2014;9(3):527-535. doi:10.2215/CJN.06380613

52. Cormican S, Connaughton DM, Kennedy C, et al. Autosomal dominant tubulointerstitial kidney disease (ADTKD) in Ireland. Ren Fail. 2019;41(1):832-841. doi:10.1080/0886022X.2019.1655452

53. Miller DT, Lee K, Gordon AS, et al. Recommendations for reporting of secondary findings in clinical exome and genome sequencing, 2021 update: a policy statement of the American College of Medical Genetics and Genomics (ACMG). Genet Med Off J Am Coll Med Genet. Published online May 20, 2021. doi:10.1038/s41436-021-01171-4

54. Knaup KX, Hackenbeck T, Popp B, et al. Biallelic Expression of Mucin-1 in Autosomal Dominant Tubulointerstitial Kidney Disease: Implications for Nongenetic Disease 
medRxiv preprint doi: https://doi.org/10.1101/2021.09.29.21264100; this version posted September 30, 2021. The copyright holder for this preprint (which was not certified by peer review) is the author/funder, who has granted medRxiv a license to display the preprint in perpetuity.

It is made available under a CC-BY 4.0 International license .

Popp \& Ekici et al. Page 20

Recognition. J Am Soc Nephrol. 2018;29(9):2298-2309. doi:10.1681/ASN.2018030245

55. Gruber AR, Lorenz R, Bernhart SH, Neuböck R, Hofacker IL. The Vienna RNA websuite. Nucleic Acids Res. 2008;36(Web Server issue):W70-74. doi:10.1093/nar/gkn188

56. Ruiz-Pesini E, Lott MT, Procaccio V, et al. An enhanced MITOMAP with a global mtDNA mutational phylogeny. Nucleic Acids Res. 2007;35(Database issue):D823-828. doi:10.1093/nar/gkl927 
medRxiv preprint doi: https://doi.org/10.1101/2021.09.29.21264100; this version posted September 30, 2021. The copyright holder for this preprint (which was not certified by peer review) is the author/funder, who has granted medRxiv a license to display the preprint in perpetuity.

It is made available under a CC-BY 4.0 International license.

Popp \& Ekici et al. Page 21

\section{SUPPLEMENTAL MATERIAL}

\section{Supplementary Notes}

Contains extended acknowledgements, supplementary methods and results, two supplementary figures, web resource links and abbreviations used.

\section{File S1}

Cohort characteristics, sequencing quality parameters and fingerprinting results. File is available through Zenodo https://doi.org/10.5281/zenodo.5516388.

\section{File S2}

Sequencing panel design/ content with information on gene domains used for Figure 2. File is available through Zenodo https://doi.org/10.5281/zenodo.5516388.

\section{File S3}

Information on small variants, CNVs and MUC1 analyses (SNaPshot and adVNTR). File is available through Zenodo https://doi.org/10.5281/zenodo.5516388.

\section{File S4}

Curated variant and individual data from the Groopman study with results of the simulation for Figure 4. File is available through Zenodo https://doi.org/10.5281/zenodo.5516388. 
medRxiv preprint doi: https://doi.org/10.1101/2021.09.29.21264100; this version posted September 30, 2021. The copyright holder for this preprint (which was not certified by peer review) is the author/funder, who has granted medRxiv a license to display the preprint in perpetuity.

It is made available under a CC-BY 4.0 International license .

Popp \& Ekici et al. Page 22

\section{TABLES}

Table 1 | Diagnostic pathogenic variants

List of all individuals who had a (likely) pathogenic variant identified and their diagnostic group/s and whether they had a renal biopsy.

\begin{tabular}{|c|c|c|c|c|c|c|}
\hline Gene & Variant & $\begin{array}{l}\text { Ty } \\
\text { pe }\end{array}$ & $\begin{array}{l}\text { Individu } \\
\text { al }\end{array}$ & $\begin{array}{l}\text { Inclusion } \\
\text { criteria }\end{array}$ & $\begin{array}{l}\text { Kidn } \\
\text { ey } \\
\text { biop } \\
\text { sy }\end{array}$ & $\begin{array}{l}\mathrm{ACM} \\
\mathbf{G}\end{array}$ \\
\hline \multirow{8}{*}{$\begin{array}{l}\text { COL4 } \\
\text { A5 }\end{array}$} & c.875G>A, p.(Gly292Glu) & $\begin{array}{l}\text { SN } \\
\mathrm{V}\end{array}$ & $\begin{array}{l}\text { Ind_924 } \\
166\end{array}$ & gout & yes & $\begin{array}{l}\text { class } \\
4 \\
(p=0 . \\
97)\end{array}$ \\
\hline & c. $1871 \mathrm{G}>\mathrm{A}$, p. (Gly624Asp) & $\begin{array}{l}\text { SN } \\
\mathrm{V}\end{array}$ & $\begin{array}{l}\text { Ind_734 } \\
367\end{array}$ & $\begin{array}{l}\text { hereditary } \\
\text { disorders }\end{array}$ & no & $\begin{array}{l}\text { class } \\
5 \\
(p=1 . \\
00)\end{array}$ \\
\hline & c. $2023 \mathrm{G}>\mathrm{A}$, p.(Gly675Ser) & $\begin{array}{l}\text { SN } \\
\mathrm{V}\end{array}$ & $\begin{array}{l}\text { Ind_408 } \\
589\end{array}$ & $\begin{array}{l}\text { hereditary } \\
\text { disorders }\end{array}$ & no & $\begin{array}{l}\text { class } \\
4 \\
(\mathrm{p}=0 . \\
90)\end{array}$ \\
\hline & c. $1871 \mathrm{G}>\mathrm{A}$, p. (Gly624Asp) & $\begin{array}{l}\text { SN } \\
\mathrm{V}\end{array}$ & $\begin{array}{l}\text { Ind_553 } \\
814\end{array}$ & $\begin{array}{l}\text { hereditary } \\
\text { disorders }\end{array}$ & yes & $\begin{array}{l}\text { class } \\
5 \\
(p=1 . \\
00)\end{array}$ \\
\hline & c. $1871 \mathrm{G}>\mathrm{A}$, p. (Gly624Asp) & $\begin{array}{l}\text { SN } \\
\mathrm{V}\end{array}$ & $\begin{array}{l}\text { Ind_674 } \\
188\end{array}$ & $\begin{array}{l}\text { hereditary } \\
\text { disorders }\end{array}$ & yes & $\begin{array}{l}\text { class } \\
5 \\
(p=1 . \\
00)\end{array}$ \\
\hline & c. $1894 \mathrm{G}>A$, p.(Gly632Ser) & $\begin{array}{l}\text { SN } \\
\mathrm{V}\end{array}$ & $\begin{array}{l}\text { Ind_523 } \\
397\end{array}$ & $\begin{array}{l}\text { hereditary } \\
\text { disorders }\end{array}$ & yes & $\begin{array}{l}\text { class } \\
4 \\
(\mathrm{p}=0 . \\
97)\end{array}$ \\
\hline & c.3196G>A, p.(Gly1066Ser) & $\begin{array}{l}\text { SN } \\
\mathrm{V}\end{array}$ & $\begin{array}{l}\text { Ind_120 } \\
641\end{array}$ & $\begin{array}{l}\text { hereditary } \\
\text { disorders }\end{array}$ & yes & $\begin{array}{l}\text { class } \\
5 \\
(p=1 . \\
00)\end{array}$ \\
\hline & c.3275G>A, p.(Gly1092Glu) & $\begin{array}{l}\text { SN } \\
\text { V }\end{array}$ & $\begin{array}{l}\text { Ind_320 } \\
658\end{array}$ & $\begin{array}{l}\text { hereditary } \\
\text { disorders }\end{array}$ & yes & $\begin{array}{l}\text { class } \\
4\end{array}$ \\
\hline
\end{tabular}


medRxiv preprint doi: https://doi.org/10.1101/2021.09.29.21264100; this version posted September 30, 2021. The copyright holder for this preprint (which was not certified by peer review) is the author/funder, who has granted medRxiv a license to display the preprint in perpetuity.

\begin{tabular}{|c|c|c|c|c|c|c|}
\hline Gene & Variant & $\begin{array}{l}\text { Ty } \\
\text { pe }\end{array}$ & $\begin{array}{l}\text { Individu } \\
\text { al }\end{array}$ & $\begin{array}{l}\text { Inclusion } \\
\text { criteria }\end{array}$ & $\begin{array}{l}\text { Kidn } \\
\text { ey } \\
\text { biop } \\
\text { sy }\end{array}$ & $\begin{array}{l}\text { ACM } \\
\text { G }\end{array}$ \\
\hline & & & & & & $\begin{array}{l}(p=0 . \\
90)\end{array}$ \\
\hline & $\begin{array}{l}\text { chrX:g.(?_107683936)_(107918 } \\
\text { 029_?)del }\end{array}$ & $\begin{array}{l}\mathrm{CN} \\
\mathrm{V}\end{array}$ & $\begin{array}{l}\text { Ind_739 } \\
404\end{array}$ & $\begin{array}{l}\text { hereditary } \\
\text { disorders }\end{array}$ & yes & $\begin{array}{l}\text { class } \\
5\end{array}$ \\
\hline & c. $1871 \mathrm{G}>A$, p.(Gly624Asp) & $\begin{array}{l}\mathrm{SN} \\
\mathrm{V}\end{array}$ & $\begin{array}{l}\text { Ind_276 } \\
132\end{array}$ & $\begin{array}{l}\lg A \\
\text { nephropathy }\end{array}$ & yes & $\begin{array}{l}\text { class } \\
5 \\
(\mathrm{p}=1 . \\
00)\end{array}$ \\
\hline & c.3508G>A, p.(Gly1170Ser) & $\begin{array}{l}\mathrm{SN} \\
\mathrm{V}\end{array}$ & $\begin{array}{l}\text { Ind_245 } \\
000\end{array}$ & $\begin{array}{l}\lg \mathrm{A} \\
\text { nephropathy; } \\
\text { chronic } \\
\text { glomerulonep } \\
\text { hritis }\end{array}$ & no & $\begin{array}{l}\text { class } \\
5 \\
(\mathrm{p}=1 . \\
00)\end{array}$ \\
\hline & c. $1871 \mathrm{G}>A$, p.(Gly624Asp) & $\begin{array}{l}\mathrm{SN} \\
\mathrm{V}\end{array}$ & $\begin{array}{l}\text { Ind_768 } \\
032\end{array}$ & $\begin{array}{l}\text { nephrosclero } \\
\text { sis }\end{array}$ & yes & $\begin{array}{l}\text { class } \\
5 \\
(p=1 . \\
00)\end{array}$ \\
\hline & c. $1871 \mathrm{G}>A$, p.(Gly624Asp) & $\begin{array}{l}\mathrm{SN} \\
\mathrm{V}\end{array}$ & $\begin{array}{l}\text { Ind_197 } \\
144\end{array}$ & $\begin{array}{l}\text { nephrosclero } \\
\text { sis }\end{array}$ & yes & $\begin{array}{l}\text { class } \\
5 \\
(\mathrm{p}=1 . \\
00)\end{array}$ \\
\hline & c. $1871 \mathrm{G}>A$, p.(Gly624Asp) & $\begin{array}{l}\mathrm{SN} \\
\mathrm{V}\end{array}$ & $\begin{array}{l}\text { Ind_905 } \\
960\end{array}$ & $\begin{array}{l}\text { nephrosclero } \\
\text { sis }\end{array}$ & yes & $\begin{array}{l}\text { class } \\
5 \\
(p=1 . \\
00)\end{array}$ \\
\hline & c.1871G>A, p.(Gly624Asp) & $\begin{array}{l}\mathrm{SN} \\
\mathrm{V}\end{array}$ & $\begin{array}{l}\text { Ind_540 } \\
052\end{array}$ & $\begin{array}{l}\text { nephrosclero } \\
\text { sis; gout }\end{array}$ & yes & $\begin{array}{l}\text { class } \\
5 \\
(\mathrm{p}=1 . \\
00)\end{array}$ \\
\hline & c.1871G>A, p.(Gly624Asp) & $\begin{array}{l}\mathrm{SN} \\
\mathrm{V}\end{array}$ & $\begin{array}{l}\text { Ind_902 } \\
111\end{array}$ & unknown & no & $\begin{array}{l}\text { class } \\
5 \\
(p=1 . \\
00)\end{array}$ \\
\hline $\begin{array}{l}\text { COL4 } \\
\text { A4 }\end{array}$ & c.5048G>A, p.(Cys1683Tyr) & $\begin{array}{l}\mathrm{SN} \\
\mathrm{V}\end{array}$ & $\begin{array}{l}\text { Ind_330 } \\
223\end{array}$ & $\begin{array}{l}\text { hereditary } \\
\text { disorders }\end{array}$ & no & $\begin{array}{l}\text { class } \\
4 \\
(\mathrm{p}=0 .\end{array}$ \\
\hline
\end{tabular}


medRxiv preprint doi: https://doi.org/10.1101/2021.09.29.21264100; this version posted September 30, 2021. The copyright holder for this preprint (which was not certified by peer review) is the author/funder, who has granted medRxiv a license to display the preprint in perpetuity.

\begin{tabular}{|c|c|c|c|c|c|c|}
\hline Gene & Variant & $\begin{array}{l}\text { Ty } \\
\text { pe }\end{array}$ & $\begin{array}{l}\text { Individu } \\
\text { al }\end{array}$ & $\begin{array}{l}\text { Inclusion } \\
\text { criteria }\end{array}$ & $\begin{array}{l}\text { Kidn } \\
\text { ey } \\
\text { biop } \\
\text { sy }\end{array}$ & $\begin{array}{l}\text { ACM } \\
\text { G }\end{array}$ \\
\hline & & & & & & 90) \\
\hline & c.2242G>A, p.(Gly748Ser) & $\begin{array}{l}\text { SN } \\
\mathrm{V}\end{array}$ & $\begin{array}{l}\text { Ind_203 } \\
846\end{array}$ & $\begin{array}{l}\lg A \\
\text { nephropathy }\end{array}$ & yes & $\begin{array}{l}\text { class } \\
4 \\
(p=0 . \\
90)\end{array}$ \\
\hline & c.4832G>A, p.(Gly1611Glu) & $\begin{array}{l}\text { SN } \\
\mathrm{V}\end{array}$ & $\begin{array}{l}\text { Ind_641 } \\
864\end{array}$ & $\begin{array}{l}\lg A \\
\text { nephropathy }\end{array}$ & yes & $\begin{array}{l}\text { class } \\
4 \\
(p=0 . \\
90)\end{array}$ \\
\hline & c.735G >A, p.[(=);0?] & $\begin{array}{l}\text { SN } \\
\mathrm{V}\end{array}$ & $\begin{array}{l}\text { Ind_251 } \\
195\end{array}$ & $\begin{array}{l}\text { nephrosclero } \\
\text { sis }\end{array}$ & yes & $\begin{array}{l}\text { class } \\
4 \\
(p=0 . \\
90)\end{array}$ \\
\hline & c.3707G>A, p.(Gly1236Glu) & $\begin{array}{l}\text { SN } \\
\mathrm{V}\end{array}$ & $\begin{array}{l}\text { Ind_591 } \\
007\end{array}$ & $\begin{array}{l}\text { nephrosclero } \\
\text { sis; interstitial } \\
\text { nephritis }\end{array}$ & yes & $\begin{array}{l}\text { class } \\
4 \\
(p=0 . \\
90)\end{array}$ \\
\hline & c.93_94del, p.(Ser32Cysfs*28) & $\begin{array}{l}\text { ind } \\
\text { el }\end{array}$ & $\begin{array}{l}\text { Ind_805 } \\
187\end{array}$ & unknown & no & $\begin{array}{l}\text { class } \\
5 \\
(p=1 . \\
00)\end{array}$ \\
\hline & c.736G>A, p.(Gly246Ser) & $\begin{array}{l}\text { SN } \\
\mathrm{V}\end{array}$ & $\begin{array}{l}\text { Ind_218 } \\
190\end{array}$ & unknown & no & $\begin{array}{l}\text { class } \\
4 \\
(\mathrm{p}=0 . \\
97)\end{array}$ \\
\hline & $\begin{array}{l}\text { c.1935_1952del, } \\
\text { p.(Pro647_Val652del) }\end{array}$ & $\begin{array}{l}\text { ind } \\
\text { el }\end{array}$ & $\begin{array}{l}\text { Ind_712 } \\
115\end{array}$ & unknown & no & $\begin{array}{l}\text { class } \\
4 \\
(p=0 . \\
99)\end{array}$ \\
\hline \multirow{2}{*}{$\begin{array}{l}\text { COL4 } \\
A 3\end{array}$} & c.688G>A, p.(Gly230Ser) & $\begin{array}{l}\text { SN } \\
\mathrm{V}\end{array}$ & $\begin{array}{l}\text { Ind_800 } \\
358\end{array}$ & gout & no & $\begin{array}{l}\text { class } \\
4 \\
(p=0 . \\
90)\end{array}$ \\
\hline & c.1595G>A, p.(Gly532Asp) & $\begin{array}{l}\text { SN } \\
\mathrm{V}\end{array}$ & $\begin{array}{l}\text { Ind_977 } \\
173\end{array}$ & $\begin{array}{l}\text { gout; } \\
\text { hereditary }\end{array}$ & no & $\begin{array}{l}\text { class } \\
4 \\
(p=0 .\end{array}$ \\
\hline
\end{tabular}


medRxiv preprint doi: https://doi.org/10.1101/2021.09.29.21264100; this version posted September 30, 2021. The copyright holder for this preprint (which was not certified by peer review) is the author/funder, who has granted medRxiv a license to display the preprint in perpetuity.

\begin{tabular}{|c|c|c|c|c|c|c|}
\hline Gene & Variant & $\begin{array}{l}\text { Ty } \\
\text { pe }\end{array}$ & $\begin{array}{l}\text { Individu } \\
\text { al }\end{array}$ & $\begin{array}{l}\text { Inclusion } \\
\text { criteria }\end{array}$ & $\begin{array}{l}\text { Kidn } \\
\text { ey } \\
\text { biop } \\
\text { sy }\end{array}$ & $\begin{array}{l}\text { ACM } \\
\text { G }\end{array}$ \\
\hline & & & & disorders & & 97) \\
\hline & c.1559G>A, p.(Gly520Asp) & $\begin{array}{l}\text { SN } \\
V\end{array}$ & $\begin{array}{l}\text { Ind_553 } \\
814\end{array}$ & $\begin{array}{l}\text { hereditary } \\
\text { disorders }\end{array}$ & yes & $\begin{array}{l}\text { class } \\
4 \\
(p=0 . \\
97)\end{array}$ \\
\hline & c.4388G>C, p.(Gly1463Ala) & $\begin{array}{l}\text { SN } \\
\text { V }\end{array}$ & $\begin{array}{l}\text { Ind_458 } \\
246\end{array}$ & $\begin{array}{l}\lg \mathrm{A} \\
\text { nephropathy }\end{array}$ & yes & $\begin{array}{l}\text { class } \\
4 \\
(p=0 . \\
90)\end{array}$ \\
\hline \multirow{4}{*}{$\begin{array}{l}\text { HNF1 } \\
B\end{array}$} & $\begin{array}{l}\text { chr17:g.(?_34914860)_(361050 } \\
\text { 69_?)dup }\end{array}$ & $\begin{array}{l}\mathrm{CN} \\
\mathrm{V}\end{array}$ & $\begin{array}{l}\text { Ind_207 } \\
310\end{array}$ & $\begin{array}{l}\text { nephrosclero } \\
\text { sis }\end{array}$ & no & $\begin{array}{l}\text { class } \\
5\end{array}$ \\
\hline & c. $742 \mathrm{C}>\mathrm{G}$, p.(Gln248Glu) & $\begin{array}{l}\text { SN } \\
\mathrm{V}\end{array}$ & $\begin{array}{l}\text { Ind_197 } \\
144\end{array}$ & $\begin{array}{l}\text { nephrosclero } \\
\text { sis }\end{array}$ & yes & $\begin{array}{l}\text { class } \\
4 \\
(p=0 . \\
90)\end{array}$ \\
\hline & c. $810-1 \mathrm{G}>\mathrm{A}, \mathrm{p} .0 ?$ & $\begin{array}{l}\text { SN } \\
\text { V }\end{array}$ & $\begin{array}{l}\text { Ind_861 } \\
194\end{array}$ & others & no & $\begin{array}{l}\text { class } \\
5 \\
(\mathrm{p}=1 . \\
00)\end{array}$ \\
\hline & $\begin{array}{l}\text { chr17:g.(?_34475214)_(365041 } \\
\text { 24_?)del }\end{array}$ & $\begin{array}{l}\mathrm{CN} \\
\mathrm{V}\end{array}$ & $\begin{array}{l}\text { Ind_958 } \\
149\end{array}$ & unknown & no & $\begin{array}{l}\text { class } \\
5\end{array}$ \\
\hline \multirow{3}{*}{$\begin{array}{l}\text { UMO } \\
D\end{array}$} & c.608G>A, p.(Cys203Tyr) & $\begin{array}{l}\text { SN } \\
\text { V }\end{array}$ & $\begin{array}{l}\text { Ind_725 } \\
568\end{array}$ & $\begin{array}{l}\text { interstitial } \\
\text { nephritis }\end{array}$ & no & $\begin{array}{l}\text { class } \\
5 \\
(p=1 . \\
00)\end{array}$ \\
\hline & c.673G>T, p.(Gly225Cys) & $\begin{array}{l}\text { SN } \\
V\end{array}$ & $\begin{array}{l}\text { Ind_395 } \\
543\end{array}$ & $\begin{array}{l}\text { interstitial } \\
\text { nephritis }\end{array}$ & yes & $\begin{array}{l}\text { class } \\
4 \\
(p=0 . \\
90)\end{array}$ \\
\hline & c.548G>A, p.(Cys183Tyr) & $\begin{array}{l}\text { SN } \\
\text { V }\end{array}$ & $\begin{array}{l}\text { Ind_777 } \\
983\end{array}$ & $\begin{array}{l}\text { nephrosclero } \\
\text { sis; interstitial } \\
\text { nephritis }\end{array}$ & no & $\begin{array}{l}\text { class } \\
4 \\
(p=0 . \\
97)\end{array}$ \\
\hline $\begin{array}{l}M T- \\
T F\end{array}$ & chrM:g.616T>C & $\begin{array}{l}\text { SN } \\
V\end{array}$ & $\begin{array}{l}\text { Ind_151 } \\
715\end{array}$ & unknown & no & $\begin{array}{l}\text { class } \\
5\end{array}$ \\
\hline
\end{tabular}


medRxiv preprint doi: https://doi.org/10.1101/2021.09.29.21264100; this version posted September 30, 2021. The copyright holder for this preprint (which was not certified by peer review) is the author/funder, who has granted medRxiv a license to display the preprint in perpetuity.

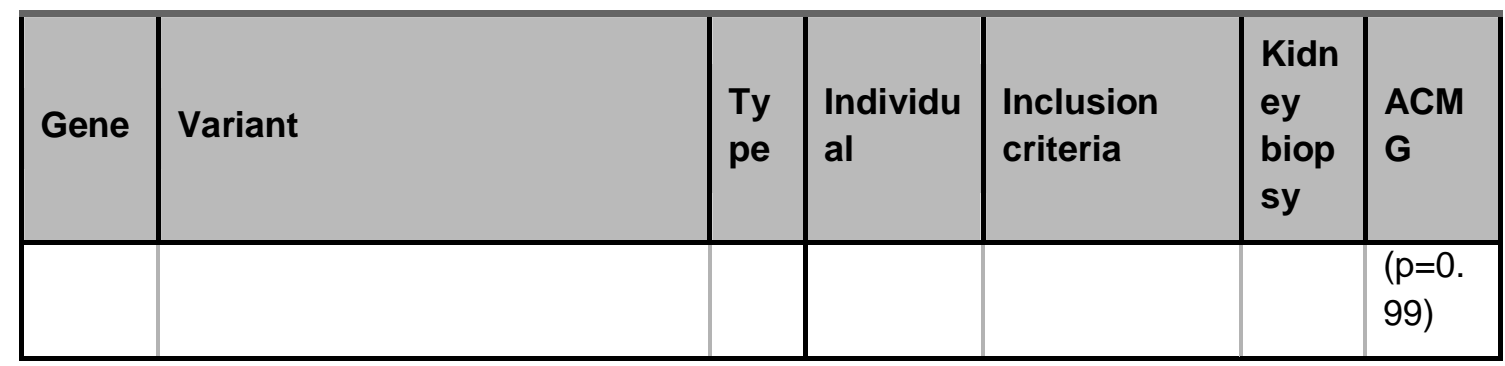

Table 2 | Additional variants of unknown significance

List of all individuals who had a VUS identified and their diagnostic group/s and whether they had a renal biopsy.

\begin{tabular}{|c|c|c|c|c|c|c|}
\hline Gene & Variant & $\begin{array}{l}\text { Typ } \\
\text { e }\end{array}$ & Individual & Inclusion criteria & $\begin{array}{l}\text { Kidne } \\
\text { y } \\
\text { biopsy }\end{array}$ & ACMG \\
\hline \multirow{6}{*}{ COL4A3 } & $\begin{array}{l}\text { c. } 685 \mathrm{C}>\mathrm{T}, \\
\text { p. }(\operatorname{Arg} 229 \operatorname{Trp})\end{array}$ & SNV & $\begin{array}{l}\text { Ind_58162 } \\
1\end{array}$ & nephrosclerosis & no & $\begin{array}{l}\text { class } 3 \\
(p=0.50 \\
)\end{array}$ \\
\hline & $\begin{array}{l}\text { c. } 1052 A>C, \\
\text { p. (Gln351Pro) }\end{array}$ & SNV & $\begin{array}{l}\text { Ind_19091 } \\
0\end{array}$ & nephrosclerosis & no & $\begin{array}{l}\text { class } 3 \\
(p=0.19 \\
)\end{array}$ \\
\hline & $\begin{array}{l}\text { c. } 4421 \mathrm{~T}>\mathrm{C}, \\
\text { p.(Leu1474Pro) }\end{array}$ & SNV & $\begin{array}{l}\text { Ind_50127 } \\
9\end{array}$ & $\begin{array}{l}\text { chronic } \\
\text { glomerulonephriti } \\
\mathrm{s}\end{array}$ & no & $\begin{array}{l}\text { class } 3 \\
(p=0.19 \\
)\end{array}$ \\
\hline & $\begin{array}{l}\text { c. } 4523 A>G \text {, } \\
\text { p.(Asn1508Ser } \\
\text { ) }\end{array}$ & SNV & $\begin{array}{l}\text { Ind_80518 } \\
7\end{array}$ & unknown & no & $\begin{array}{l}\text { class } 3 \\
(p=0.19 \\
)\end{array}$ \\
\hline & $\begin{array}{l}\text { c. } 897 \mathrm{C}>\mathrm{T}, \\
\text { p. }(=)\end{array}$ & SNV & $\begin{array}{l}\text { Ind_31342 } \\
7\end{array}$ & IgA nephropathy & yes & $\begin{array}{l}\text { class } 3 \\
(p=0.10 \\
)\end{array}$ \\
\hline & $\begin{array}{l}\text { c. } 4782 \mathrm{C}>\mathrm{T}, \\
\text { p. }(=)\end{array}$ & SNV & $\begin{array}{l}\text { Ind_48598 } \\
4\end{array}$ & nephrosclerosis & yes & $\begin{array}{l}\text { class } 3 \\
(p=0.10 \\
)\end{array}$ \\
\hline \multirow{2}{*}{ МYH9 } & $\begin{array}{l}\text { c.979A }>\text { T, } \\
\text { p. (Arg327Trp) }\end{array}$ & SNV & $\begin{array}{l}\text { Ind_22016 } \\
3\end{array}$ & others & no & $\begin{array}{l}\text { class } 3 \\
(p=0.68 \\
)\end{array}$ \\
\hline & $\begin{array}{l}\text { c. } 490+47 G>A \text {, } \\
\text { p. } ?\end{array}$ & SNV & $\begin{array}{l}\text { Ind_20083 } \\
4\end{array}$ & nephrosclerosis & yes & $\begin{array}{l}\text { class } 3 \\
(p=0.32 \\
)\end{array}$ \\
\hline
\end{tabular}


medRxiv preprint doi: https://doi.org/10.1101/2021.09.29.21264100; this version posted September 30, 2021. The copyright holder for this preprint (which was not certified by peer review) is the author/funder, who has granted medRxiv a license to display the preprint in perpetuity.

\begin{tabular}{|c|c|c|c|c|c|c|}
\hline Gene & Variant & $\begin{array}{l}\text { Typ } \\
\text { e }\end{array}$ & Individual & Inclusion criteria & $\begin{array}{l}\text { Kidne } \\
\text { y } \\
\text { biopsy }\end{array}$ & ACMG \\
\hline & $\begin{array}{l}\text { c. } 2041 G>A \text {, } \\
\text { p. (Gly681Ser) }\end{array}$ & SNV & $\begin{array}{l}\text { Ind_39999 } \\
7\end{array}$ & nephrosclerosis & yes & $\begin{array}{l}\text { class } 3 \\
(p=0.19 \\
)\end{array}$ \\
\hline & $\begin{array}{l}\text { c. } 3340 \mathrm{~T}>\mathrm{C}, \\
\text { p.(Ser1114Pro) }\end{array}$ & SNV & $\begin{array}{l}\text { Ind_27980 } \\
7\end{array}$ & nephrosclerosis & yes & $\begin{array}{l}\text { class } 3 \\
(p=0.19 \\
)\end{array}$ \\
\hline & $\begin{array}{l}\text { c. } 3340 \mathrm{~T}>\mathrm{C}, \\
\text { p.(Ser1114Pro) }\end{array}$ & SNV & $\begin{array}{l}\text { Ind_70203 } \\
4\end{array}$ & unknown & no & $\begin{array}{l}\text { class } 3 \\
(p=0.19 \\
)\end{array}$ \\
\hline & $\begin{array}{l}\text { c. } 5128 \mathrm{~A}>\mathrm{G}, \\
\text { p. }(\mathrm{lle} 1710 \mathrm{Val})\end{array}$ & SNV & $\begin{array}{l}\text { Ind_81914 } \\
7\end{array}$ & $\begin{array}{l}\text { chronic } \\
\text { glomerulonephriti } \\
\mathrm{s}\end{array}$ & yes & $\begin{array}{l}\text { class } 3 \\
(p=0.10 \\
)\end{array}$ \\
\hline \multirow{4}{*}{ COL4A4 } & $\begin{array}{l}\text { c. } 4963 \mathrm{G}>\mathrm{A}, \\
\text { p. }(\text { Val1655Met })\end{array}$ & SNV & $\begin{array}{l}\text { Ind_52753 } \\
1\end{array}$ & others & no & $\begin{array}{l}\text { class } 3 \\
(p=0.68 \\
)\end{array}$ \\
\hline & $\begin{array}{l}\text { c. } 5045 G>A, \\
\text { p. }(\operatorname{Arg} 1682 G \mid n)\end{array}$ & SNV & $\begin{array}{l}\text { Ind_25793 } \\
3\end{array}$ & $\begin{array}{l}\text { hereditary } \\
\text { disorders }\end{array}$ & no & $\begin{array}{l}\text { class } 3 \\
(p=0.32 \\
)\end{array}$ \\
\hline & $\begin{array}{l}\text { c. } 1770 A>T \text {, } \\
\text { p. }(=)\end{array}$ & SNV & $\begin{array}{l}\text { Ind_79107 } \\
5\end{array}$ & nephrosclerosis & no & $\begin{array}{l}\text { class } 3 \\
(p=0.19 \\
)\end{array}$ \\
\hline & $\begin{array}{l}\text { c. } 3398-3 C>T \text {, } \\
\text { p.? }\end{array}$ & SNV & $\begin{array}{l}\text { Ind_75361 } \\
6\end{array}$ & nephrosclerosis & yes & $\begin{array}{l}\text { class } 3 \\
(p=0.10 \\
)\end{array}$ \\
\hline \multirow{3}{*}{ PARN } & $\begin{array}{l}\text { c. } 1319-16 \mathrm{~T}>\mathrm{A}, \\
\text { p.? }\end{array}$ & SNV & $\begin{array}{l}\text { Ind_73779 } \\
1\end{array}$ & unknown & no & $\begin{array}{l}\text { class } 3 \\
(p=0.10 \\
)\end{array}$ \\
\hline & $\begin{array}{l}\text { c. } 1330 \mathrm{C}>\mathrm{T}, \\
\text { p.(Arg444Cys) }\end{array}$ & SNV & $\begin{array}{l}\text { Ind_55443 } \\
4\end{array}$ & $\lg A$ nephropathy & yes & $\begin{array}{l}\text { class } 3 \\
(p=0.10 \\
)\end{array}$ \\
\hline & $\begin{array}{l}\text { c. } 1501 \mathrm{G}>\mathrm{T} \text {, } \\
\text { p.(Ala501Ser) }\end{array}$ & SNV & $\begin{array}{l}\text { Ind_95814 } \\
9\end{array}$ & unknown & no & $\begin{array}{l}\text { class } 3 \\
(p=0.10 \\
)\end{array}$ \\
\hline DNAJB1 & c. $973 \mathrm{G}>\mathrm{C}$ & SNV & Ind_18060 & nephrosclerosis & no & $\begin{array}{l}\text { class } 3 \\
(p=0.50\end{array}$ \\
\hline
\end{tabular}


medRxiv preprint doi: https://doi.org/10.1101/2021.09.29.21264100; this version posted September 30, 2021. The copyright holder for this preprint (which was not certified by peer review) is the author/funder, who has granted medRxiv a license to display the preprint in perpetuity.

It is made available under a CC-BY 4.0 International license .

\begin{tabular}{|c|c|c|c|c|c|c|}
\hline Gene & Variant & $\begin{array}{l}\text { Typ } \\
\text { e }\end{array}$ & Individual & Inclusion criteria & $\begin{array}{l}\text { Kidne } \\
\text { y } \\
\text { biopsy }\end{array}$ & ACMG \\
\hline \multirow[t]{2}{*}{1} & p.(Asp325His) & & 6 & & & ) \\
\hline & $\begin{array}{l}\text { c.895C>G, } \\
\text { p.(Leu299Val) }\end{array}$ & SNV & $\begin{array}{l}\text { Ind_10236 } \\
0\end{array}$ & unknown & no & $\begin{array}{l}\text { class } 3 \\
(p=0.10 \\
)\end{array}$ \\
\hline \multirow{2}{*}{$H N F 1 B$} & $\begin{array}{l}\text { c. } 1127 \mathrm{C}>\mathrm{T}, \\
\text { p. }(\text { Thr376lle })\end{array}$ & SNV & $\begin{array}{l}\text { Ind_50127 } \\
9\end{array}$ & $\begin{array}{l}\text { chronic } \\
\text { glomerulonephriti } \\
\mathrm{s}\end{array}$ & no & $\begin{array}{l}\text { class } 3 \\
(p=0.19 \\
)\end{array}$ \\
\hline & $\begin{array}{l}\text { c. } 1006 C>G \text {, } \\
\text { p. }(\text { His336Asp) }\end{array}$ & SNV & $\begin{array}{l}\text { Ind_53392 } \\
9\end{array}$ & $\begin{array}{l}\text { hereditary } \\
\text { disorders }\end{array}$ & no & $\begin{array}{l}\text { class } 3 \\
(p=0.10 \\
)\end{array}$ \\
\hline COL4A5 & $\begin{array}{l}\text { c. } 3095 T>C, \\
\text { p.(Met1032Thr) }\end{array}$ & SNV & $\begin{array}{l}\text { Ind_89086 } \\
6\end{array}$ & unknown & no & $\begin{array}{l}\text { class } 3 \\
(p=0.68 \\
)\end{array}$ \\
\hline GATM & $\begin{array}{l}\text { c. } 875 A>G, \\
\text { p.(His292Arg) }\end{array}$ & SNV & $\begin{array}{l}\text { Ind_55036 } \\
8\end{array}$ & $\begin{array}{l}\text { interstitial } \\
\text { nephritis }\end{array}$ & no & $\begin{array}{l}\text { class } 3 \\
(p=0.50 \\
)\end{array}$ \\
\hline REN & $\begin{array}{l}\text { c. } 699 \mathrm{G}>\mathrm{T}, \\
\text { p.(Glu233Asp) }\end{array}$ & SNV & $\begin{array}{l}\text { Ind_57954 } \\
0\end{array}$ & $\lg A$ nephropathy & no & $\begin{array}{l}\text { class } 3 \\
(p=0.50 \\
)\end{array}$ \\
\hline
\end{tabular}

Table 3 | Nephronophthisis carrier variants

List of all individuals in which a heterozygous (likely) pathogenic variant in 17 Nephronophthisis genes was identified together with their diagnostic group/s and whether they had a renal biopsy.

\begin{tabular}{|c|c|c|c|c|c|c|}
\hline Gene & Variant & $\begin{array}{l}\text { Typ } \\
\text { e }\end{array}$ & Individual & $\begin{array}{l}\text { Inclusion } \\
\text { criteria }\end{array}$ & $\begin{array}{l}\text { Kidne } \\
\text { y } \\
\text { biops } \\
y\end{array}$ & ACMG \\
\hline \multirow[t]{2}{*}{ NPHP3 } & $\begin{array}{l}\text { c. } 1381 G>T, \\
\text { p. }\left(G l u 461^{*}\right)\end{array}$ & SNV & $\begin{array}{l}\text { Ind_60000 } \\
0\end{array}$ & IgA nephropathy & yes & $\begin{array}{l}\text { class } 5 \\
(p=0.99 \\
)\end{array}$ \\
\hline & $\begin{array}{l}\text { c.2694-2_2694- } \\
1 \text { del, p.0? }\end{array}$ & indel & $\begin{array}{l}\text { Ind_58162 } \\
1\end{array}$ & nephrosclerosis & no & $\begin{array}{l}\text { class } 5 \\
(p=0.97\end{array}$ \\
\hline
\end{tabular}


medRxiv preprint doi: https://doi.org/10.1101/2021.09.29.21264100; this version posted September 30, 2021. The copyright holder for this preprint (which was not certified by peer review) is the author/funder, who has granted medRxiv a license to display the preprint in perpetuity.

\begin{tabular}{|c|c|c|c|c|c|c|}
\hline Gene & Variant & $\begin{array}{l}\text { Typ } \\
\text { e }\end{array}$ & Individual & $\begin{array}{l}\text { Inclusion } \\
\text { criteria }\end{array}$ & $\begin{array}{l}\text { Kidne } \\
y \\
\text { biops } \\
y\end{array}$ & ACMG \\
\hline & & & & & & ) \\
\hline & $\begin{array}{l}\text { c.2694-2_2694- } \\
1 \text { del, p.0? }\end{array}$ & indel & $\begin{array}{l}\text { Ind_83419 } \\
2\end{array}$ & $\lg A$ nephropathy & yes & $\begin{array}{l}\text { class } 5 \\
(p=0.97 \\
)\end{array}$ \\
\hline & c. $1629-2 A>G$, p.0? & SNV & $\begin{array}{l}\text { Ind_44043 } \\
9\end{array}$ & $\begin{array}{l}\text { nephrosclerosis; } \\
\text { IgA nephropathy }\end{array}$ & yes & $\begin{array}{l}\text { class } 4 \\
(p=0.90 \\
)\end{array}$ \\
\hline \multirow{2}{*}{$\begin{array}{l}\text { CEP29 } \\
0\end{array}$} & $\begin{array}{l}\text { c.5493del, } \\
\text { p.(Ala1832Profs*1 } \\
\text { 9) }\end{array}$ & indel & $\begin{array}{l}\text { Ind_61351 } \\
9\end{array}$ & IgA nephropathy & yes & $\begin{array}{l}\text { class } 5 \\
(p=0.99 \\
)\end{array}$ \\
\hline & $\begin{array}{l}\text { c.292_293insA, } \\
\left.\text { p.(Leu98Hisfs }{ }^{*} 18\right)\end{array}$ & indel & $\begin{array}{l}\text { Ind_90321 } \\
4\end{array}$ & IgA nephropathy & yes & $\begin{array}{l}\text { class } 5 \\
(p=0.99 \\
)\end{array}$ \\
\hline \multirow[b]{2}{*}{ IQCB1 } & $\begin{array}{l}\text { c.1518_1519del, } \\
\text { p.(His506Glnfs*13) }\end{array}$ & indel & $\begin{array}{l}\text { Ind_18107 } \\
0\end{array}$ & IgA nephropathy & yes & $\begin{array}{l}\text { class } 5 \\
(p=0.97 \\
)\end{array}$ \\
\hline & $\begin{array}{l}\text { c.1518_1519del, } \\
\text { p.(His506Glnfs*13) }\end{array}$ & indel & $\begin{array}{l}\text { Ind_24500 } \\
0\end{array}$ & $\begin{array}{l}\text { IgA nephropathy; } \\
\text { chronic } \\
\text { glomerulonephriti } \\
\mathrm{s}\end{array}$ & no & $\begin{array}{l}\text { class } 5 \\
(p=0.97 \\
)\end{array}$ \\
\hline ANKS6 & $\begin{array}{l}\text { c.130_157del, } \\
\left.\text { p.(Glu44Argfs }{ }^{\star} 72\right)\end{array}$ & indel & $\begin{array}{l}\text { Ind_99909 } \\
3\end{array}$ & nephrosclerosis & yes & $\begin{array}{l}\text { class } 4 \\
(p=0.90 \\
)\end{array}$ \\
\hline $\begin{array}{l}\text { TTC21 } \\
B\end{array}$ & $\begin{array}{l}\text { c. } 1715 C>A \text {, } \\
\text { p. }(\text { Ser572*) }\end{array}$ & SNV & $\begin{array}{l}\text { Ind_75316 } \\
9\end{array}$ & nephrosclerosis & no & $\begin{array}{l}\text { class } 4 \\
(p=0.90 \\
)\end{array}$ \\
\hline $\begin{array}{l}\text { ZNF42 } \\
3\end{array}$ & $\begin{array}{l}\text { c. } 2738 \mathrm{C}>\mathrm{T}, \\
\text { p.(Pro913Leu) }\end{array}$ & SNV & $\begin{array}{l}\text { Ind_89086 } \\
6\end{array}$ & unknown & no & $\begin{array}{l}\text { class } 5 \\
(p=0.97 \\
)\end{array}$ \\
\hline
\end{tabular}


medRxiv preprint doi: https://doi.org/10.1101/2021.09.29.21264100; this version posted September 30, 2021. The copyright holder for this

preprint (which was not certified by peer review) is the author/funder, who has granted medRxiv a license to display the preprint in perpetuity.

It is made available under a CC-BY 4.0 International license .

Popp \& Ekici et al. Page 30

\section{FIGURES}

\section{Figure 1 | Filtering approach and cohort characteristics}

(A) Workflow used to filter individuals from the GCKD and subsequent quality control steps to ensure DNA integrity and sample identity. Clinical category based filtering resulted in 326 entries which corresponded to 303 unique individuals (5.8\% of the whole GCKD cohort). Of these 271 (89.4\%) passed all quality control steps and were included in the final analyses. (B) Upset plot showing the distribution and overlap of the nine clinical criteria used to filter the study cohort from the GCKD cohort. (C) Age distribution by sex in the final cohort. The yaxis depicts age classes 5 -year intervals. The $x$-axis shows the number of individuals, with females on the right (red) and males on the left (blue) side. Age is reported at inclusion into the GCKD study. (D) Distribution of different kidney function parameters at GCKD study inclusion: Top (dark grey) eGFR by CKD-EPI, Middle (blue) eGFR by MDRD, Bottom (light grey) Albumin-Creatinine Ratio (ACR).

\section{Figure 2 | Diagnostic pathogenic variants}

Schematic linear protein structure with domains of genes with pathogenic variants identified in the cohort and variant positions marked by lollipops where the length of the segments corresponds to each variant's CADD score (a computational ("in silico") metric commonly used to assess the possible pathogenicity of small variants based on an ensemble of annotations like evolutionary conservation). Red dots represent variants, black dots represent variants likely truncating variants, and blue dots represent indels causing in-frame deletions. Red and blue bars with dotted margin represent deletions and duplications, respectively. Individuals with multiple variants identified are linked through the individual pseudonym marked with a "\#" under the respective variants. (A) In COL4A5 we identified 15 SNVs and one intragenic deletion. Note that nine unrelated individuals carried the c.1871G>A, p.(Gly624Asp) variant in either hemizygous (six) or heterozygous (three) states. Two individuals (\#Ind_197144, \#Ind_553814) carried this recurrent missense and another pathogenic variant. (B) The eight variants identified in COL4A4 either affected conserved glycine residues directly through a missense change (four), through an in-frame deletion (one) were likely protein truncating variants (two) or affected a cysteine residue in the Cterminal NC-domain. (C) All four variants in COL4A3 were typical glycine missense changes. One female individual carried the c.1559G>A, p.(Gly520Asp) variant with the recurrent COL4A5 variant. (D) in four individuals we identified variants affecting HNF1B. These were a missense variant in the homeodomain, a splice acceptor variant and a genomic deletion and 
medRxiv preprint doi: https://doi.org/10.1101/2021.09.29.21264100; this version posted September 30, 2021. The copyright holder for this

preprint (which was not certified by peer review) is the author/funder, who has granted medRxiv a license to display the preprint in perpetuity.

It is made available under a CC-BY 4.0 International license .

Popp \& Ekici et al. Page 31

duplication of the $17 q 12$ region, respectively. Deletion breakpoints could not be determined using the sequencing data or MLPA confirmation (red/blue fill overflowing the margin indicating this uncertainty). One female individual carried the c.742C>G, p.(GIn248Glu) variant with the recurrent $C O L 4 A 5$ variant. (E) All three pathogenic variants in $U M O D$ were typical cysteine missense variants. (F) In the mitochondrial gene MT-TF, which encodes the tRNA for phenylalanine, a homoplastic SNV was identified and confirmed. The variant affects the anticodon as predicted through the RNAfold web server ${ }^{55}$ and has been listed as pathogenic in MITOMAP ${ }^{56}$. (G) Schematic of the MUC1 protein domain structure and the usually unknown position of the typical cytosine duplication ("c.428dupC") causing a toxic neo-protein in the VNTR region between exons 2 and 3. Bioinformatic search using adVNTR identified no variant and successful "gold standard" SNaPshot in 228 also identified no positive case in the cohort. Grey dashed line used to separate MUC1 from genes with diagnostic variants in the cohort. Please compare File $S 2^{35}$ sheet "domains" for full information on gene protein domains.

\section{Figure 3 | Pathogenic variants by clinical criteria}

(A) Stacked bar plot indicating the fraction of individuals with a pathogenic variant identified split by the nine clinical filtering criteria. As some individuals fulfilled multiple criteria we split them by diagnosis. This resulted in 292 total combinations of individuals and clinical criteria and 39 such combinations for individuals with a genetic diagnosis. To test whether certain criteria are enriched for genetic findings, we calculated p-values assuming an equal diagnostic rate of 39/292 in a simple Bernoulli experiment using a binomial test. Categories "hereditary disorders" ( $p \sim 0.000014$ ) and "gout" ( $p$ 0.023) showed nominally significant enrichment. The "hereditary disorders" category remained significant after adjusting for multiple testing. (B) Waffle plot comparing the nine filtering criteria and the gene in which a variant has been identified. Note that the 39 combinations of individuals and criteria are now also split by gene, because two individuals in the cohort had multiple pathogenic variants, resulting in 41 combinations. The two significant categories from $A$ are all explained through variants in the COL4-genes. Interestingly all three UMOD variants identified fall in the "interstitial nephritis" category, with one of them additionally classified as "nephrosclerosis". Variants affecting HNF1B are either dispersed through four categories with none of them in the hereditary category, confirming both the variability in the HNF1B-associated disorders and the often sporadic nature of the CNVs (17q12 microdeletion/ -duplication syndromes). Compare File $\mathrm{S3}^{35}$ for full variant details. (C) Violin and scatter plots comparing the kidney 
medRxiv preprint doi: https://doi.org/10.1101/2021.09.29.21264100; this version posted September 30, 2021. The copyright holder for this

preprint (which was not certified by peer review) is the author/funder, who has granted medRxiv a license to display the preprint in perpetuity.

It is made available under a CC-BY 4.0 International license .

Popp \& Ekici et al. Page 32

function parameters from Figure 1D between individuals with a genetic variant identified (34) or not (237; green circles). Individuals with a COL4-variant are presented in red and with variants in other genes in blue. Individuals with two variants are marked as diamonds. Individuals with IgA nephropathy are marked with yellow margin (compare also Figure S2). The ACR at GCKD study inclusion is significantly higher in individuals with a genetic variant identified (two sided Wilcoxon signed-rank test). (D) Upset plot showing the overlaps for individuals with a suspected "hereditary diagnosis" (as used for filtering), our finding of a pathogenic variant ("diagnosis") and kidney biopsies performed. Overall only in six individuals with a confirmed diagnosis a kidney biopsy had been performed previously which likely raised the suspicion of an underlying genetic disorder. In 12 individuals with kidney biopsy where we identified pathogenic variants no suspicion of a hereditary disease was issued.

\section{Figure 4 | Diagnostic yield in panel and exome}

(A) Violin and scatter plots of 10.000 simulations randomly drawing 271 individuals from the 3,315 individuals reported by Groopman et al. and subset whether the reported variants would be detectable by exome (green) or our targeted panel (red). Estimated p-value for the yield in our cohort (green dot) $<0.0001$. To exclude differences in variant classification between the two studies, we classified both our and all variants from the Groopman study using two automated ACMG classifiers which excluded all variants not classified as (likely) pathogenic from both cohorts. This gave similar results to the first simulation and thus excluded systematic differences in manual variant classification causing our higher yield (compare Figure S1). (B) To exclude unexpected enrichment for Collagen-4 genes, we further compared the fraction of COL4-gene variants in these simulations which showed no significant difference ( $p$-simulated $\sim 0.43$ ) to the fraction $(26 / 30 \sim 86.7 \%$ ) observed in our cohort. Therefore, one could consider the COL4-variants as background, which would leave five small variants in ADTKD genes in our cohort, representing an enrichment of $\sim 5.1$ fold when compared to the Groopman cohort (calculation: $(5 / 271)$ / $(12 / 3,315)$ ). Compare Figure $\mathrm{S} 1$ for automated classification results. Compare File $S 4^{35}$ for full simulation results.

\section{Figure 5 | Proposed clinically enhanced exome design and evaluation workflow}

(A) Schematic figure explaining short read sequencing based panel and exome sequencing (ES) and their respective advantages. ES covers all coding exons but has gaps in complex regions (like the MUC1-VNTR or PKD1 duplicated exons), may miss clinically relevant intronic variants and has low coverage for mtDNA. Custom panels in contrast can be 
medRxiv preprint doi: https://doi.org/10.1101/2021.09.29.21264100; this version posted September 30, 2021. The copyright holder for this preprint (which was not certified by peer review) is the author/funder, who has granted medRxiv a license to display the preprint in perpetuity.

It is made available under a CC-BY 4.0 International license .

Popp \& Ekici et al. Page 33

designed to have high coverage of these regions but would need to be iteratively redesigned and re-sequenced for each possible disease entity. An ES target design enhanced through expert knowledge (several companies nowadays offer adding custom capture probes) allows adapting the design to the respective diagnostic needs (ceES). (B) Our proposed workflow to select patients for genetic diagnosis is based on positive family history, syndromic disease (e.g. multiple organ systems affected) and isolated simplex cases without secondary cause of CKD younger than 50 years. Genetic diagnostics should be based on clinically selected virtual panels and include ACMG recommended secondary findings and COL4-genes. Depending on the outcome and whether eventual variants explain the phenotype of the patient the ceES data should be opened to research analysis enhanced by possible RNA analyses and functional tests using e.g. renal tubular cells to finally reach a genetic diagnosis. 
A GCKD cohort

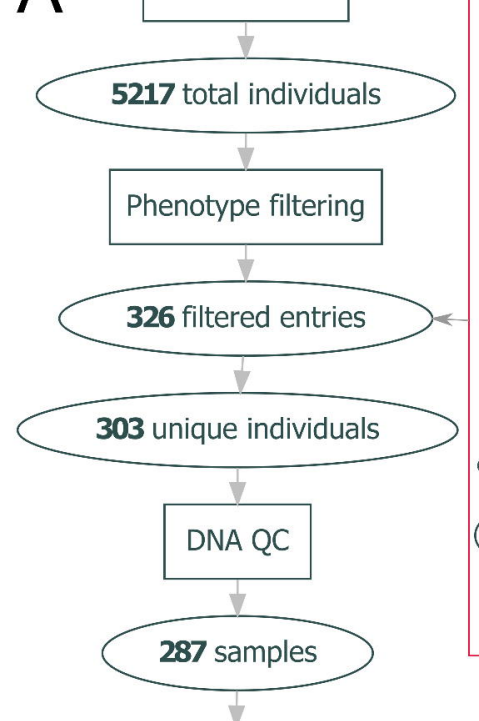

Panel sequencing

Fingerprinting and sex match

$\checkmark$

271 included individuals nephrosclerosis: 108

IgA nephropathy: 78

IgA nephropathy: 78

unknown: 54

interctitial nephritis: 27

itial nephritis: 27

others: 20

hereditary disorders: 18

(hronic glomenlonephitis: 9

chronic glomerulonephritis: 9

gout: 9

analgesic nephropathy: 3

sic nephropathy: 3

analosi

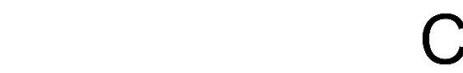

C

D

Е 100

$\stackrel{m}{\stackrel{2}{5}}$

है

25

1616

0 - analgesic nephropathy coutc glomerulone others unknown ggA nephropathy
nephrosclerosis

$\because \div 8:$

?
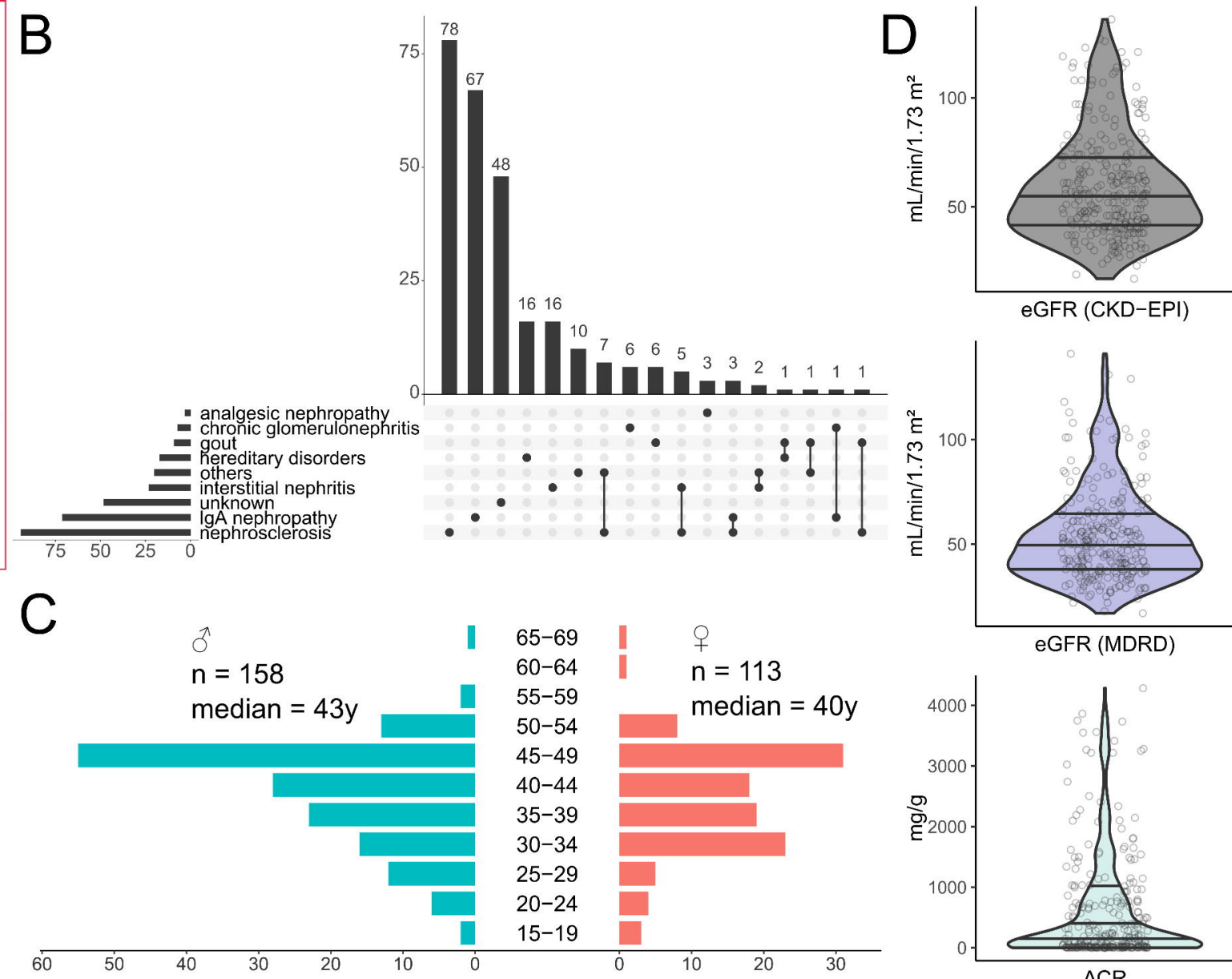


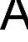

$(0<0.001)$

Diagnosis

ns

ns

ns

ns

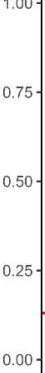

$41.2 \%(7)$

$55.6 \%(5)$

$58.8 \%(10)$

$44.4 \%(4)$

$\overline{17.4 \%(4)}$

$14.3 \%(1)$

$12.5 \%(6)$

$8.5 \%(8)$

$7.0 \%(5)$

$5.0 \%(1) \quad 0.0 \%(0)$

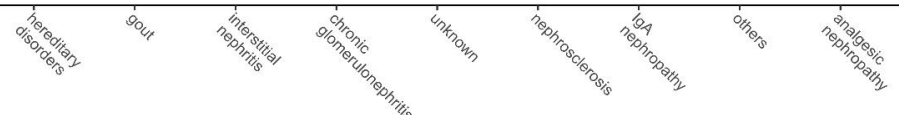

B
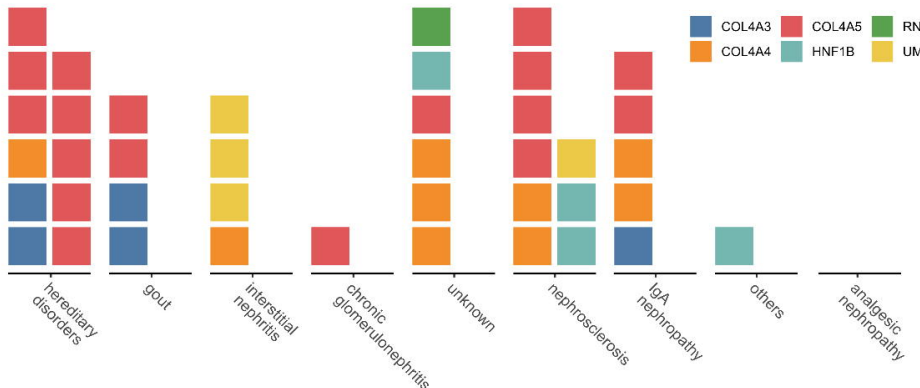

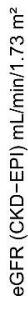
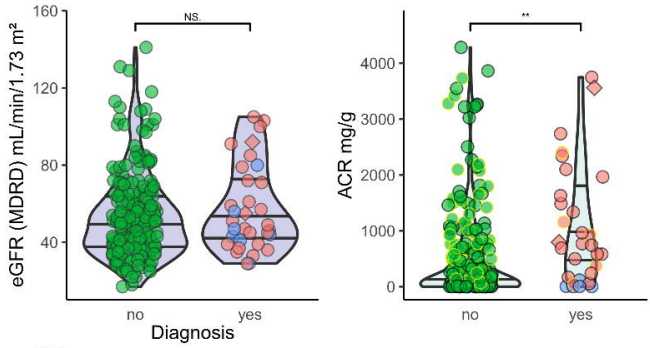

D

${ }^{120}$

105

90

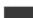

60.

30

$12080 \quad 40 \quad$ kidney biopsy

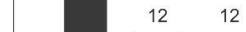

0

- hereditary disorders

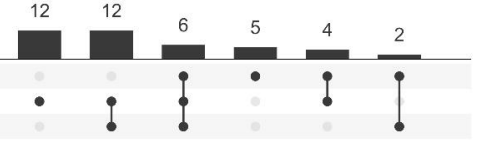




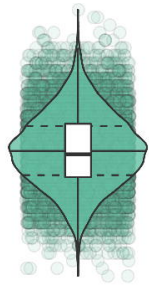

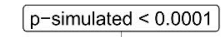

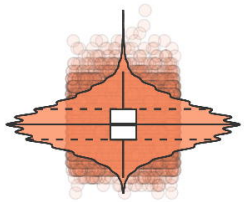

pane

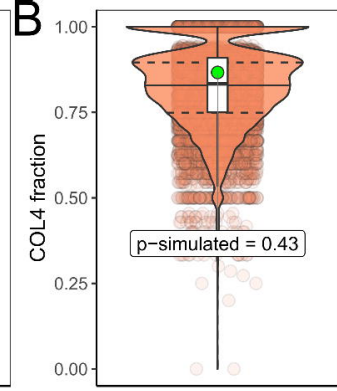



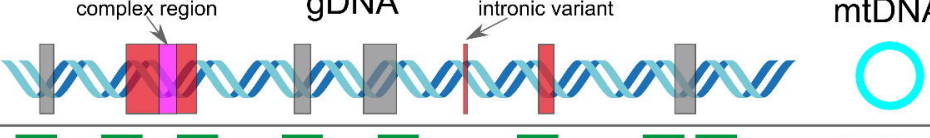

exome

panel
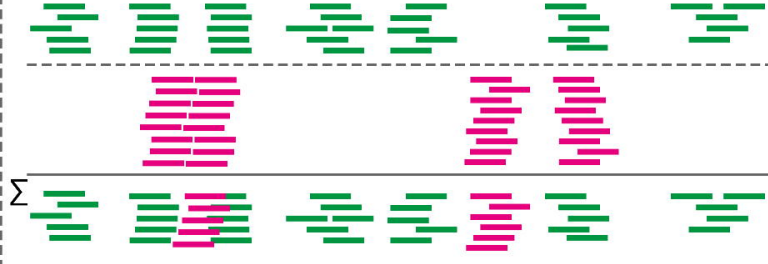

+Bioinformatics

CNVs

repeats

mitochondria repeats

B
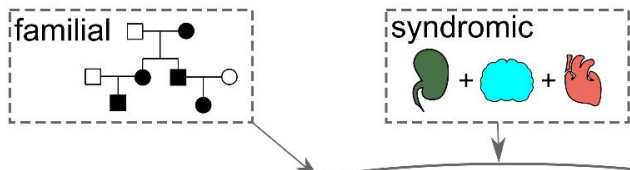

clinical evaluation for best clinical CKD entity

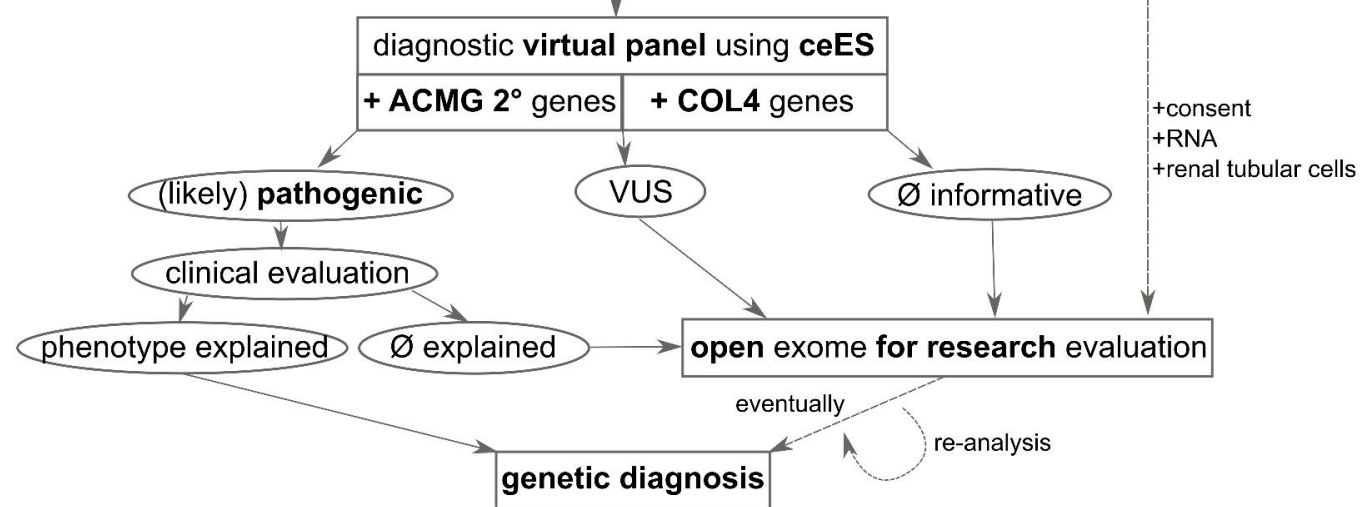

